\title{
Pengaruh Pengangguran, Indeks Pembangunan Manusia dan PDRB Terhadap Tingkat Kemiskinan di Kabupaten Luwu Timur
}

\author{
M. Mujahid Shaleh', Syahrir Mallongi², Zainuddin Rahman ${ }^{3}$ \\ ${ }^{1}$ Magister Manajemen Program Pascasarjana, Universitas Muslim Indonesia \\ 2,3 Fakultas Ekonomi dan Bisnis, Universitas Muslim Indonesia \\ Email Korespondensi: mujahid.shaleh@yahoo.com
}

\begin{abstract}
Abstrak
Penelitian ini dilakukan dengan bertujuan untuk menganalisis Pengaruh Pengangguran terhadap Tingkat Kemiskinan, Pengaruh Indeks Pembangunan Manusia terhadap Tingkat Kemiskinan, Pengaruh Produk Domestik Regional Bruto (PDRB) terhadap Tingkat Kemiskinan, dan Pengaruh Pengangguran, Indeks Pembangunan Manusia Dan Produk Domestik Regional Bruto (PDRB) terhadap Tingkat Kemiskinan. Penelitian ini menggunakan data sekunder yang diperoleh dari Badan Pusat Statistik dan sumber lain yang terkait. Data di analisis dengan Model Regresi Linear Berganda dengan menggunakan Aplikasi SPSS 26. Hasil Penelitian ini menunjukkan bahwa : (1) Secara Parsial Pengangguran Berpengaruh Positif dan tidak signifikan terhadap Tingkat Kemiskinan; (2) Secara Parsial Indeks Pembangunan Manusia dan PDRB Berpengaruh Negatif dan tidak signifikan terhadap Tingkat Kemiskinan; (3) Secara Simultan Pengangguran, Indeks Pembangunan Manusia Dan Produk Domestik Regional Bruto (PDRB) Berpengaruh Signifikan terhadap Tingkat Kemiskinan. Hasil Penelitian tersebut mengindikasikan bahwa untuk menurunkan Tingkat Kemiskinan di Kabupaten Luwu Timur secara signifikan maka ketiga Variabel Independen tersebut harus menjadi perhatian Pemerintah Kabupaten Luwu Timur dalam mengambil kebijakan-kebijakan pembangunan.
\end{abstract}

Kata Kunci: Kemiskinan, Pengangguran, Indek Pembangunan Manusia, PDRB

\section{Pendahuluan}

Kemiskinan merupakan isu global yang dihadapi oleh banyak negara di dunia, termasuk Indonesia. Dalam Tujuan Pembangunan Berkelanjutan (TPB) atau Sustainable Development Goals (SDGs), penurunan kemiskinan menjadi isu yang mendapatkan perhatian serius. Hal ini terbukti dengan masuknya penurunan kemiskinan dan kelaparan sebagai tujuan pertama dan kedua, serta dibangunnya komitmen global untuk mengakhiri kemiskinan dalam bentuk apapun. LeBaron (2014) menyebutkan bahwa kemiskinan yang semakin meluas serta angka yang tinggi merupakan inti dari semua masalah pembangunan. Kemiskinan merupakan masalah multidimensi yang berkaitan dengan berbagai aspek kehidupan dan penghidupan manusia, baik aspek ekonomi, politik, sosial budaya, psikologi, teknologi, dan lainnya, yang saling terkait secara erat satu dengan lainnya (Olilingo \& Putra, 2020). Oleh karenanya, upaya pengentasan kemiskinan membutuhkan waktu, strategi, dan sumber daya yang perlu disinergikan untuk menyelesaikannya.

Berdasarkan Undang-Undang 13 Tahun 2011, Fakir miskin adalah orang yang sama sekali tidak mempunyai sumber mata pencaharian dan/atau mempunyai sumber mata pencaharian tetapi tidak mempunyai kemampuan memenuhi kebutuhan dasar yang layak bagi kehidupan dirinya dan/atau keluarganya. Kebutuhan dasar adalah kebutuhan pangan, sandang, perumahan, kesehatan, pendidikan, pekerjaan, dan/atau pelayanan sosial. Menurut Peraturan Presiden Republik Indonesia Nomor 96 Tahun 2015 Tentang Perubahan Atas Peraturan Presiden Nomor 15 Tahun 2010 Tentang Percepatan Penanggulangan Kemiskinan, Program Penanggulangan Kemiskinan adalah kegiatan yang dilakukan oleh Pemerintah, Pemerintah Daerah, Dunia Usaha, serta masyarakat untuk meningkatkan kesejahteraan masyarakat miskin melalui bantuan sosial, pemberdayaan masyarakat, 
pemberdayaan usaha ekonomi mikro dan kecil, serta program lain dalam rangka meningkatkan kegiatan ekonomi.

Dengan berbagai kebijakan dan program pengentasan kemiskinan yang dilakukan, angka kemiskinan di Indonesia berhasil turun dari 60 persen pada tahun 1970, hingga akhirnya menembus angka satu digit yaitu 9,41 persen pada Maret 2019 dan turun kembali menjadi 9,22 persen pada September 2019. Walapun Persentase penduduk miskin pada September 2020 tercatat sebesar 10,19 persen, meningkat 0,41 persen poin terhadap Maret 2020 dan meningkat 0,97 persen poin terhadap September 2019. Kenaikan jumlah dan persentase penduduk miskin pada periode Maret 2020 dan September 2020 disebabkan oleh adanya Pandemi COVID-19 yang melanda Indonesia. Tingkat Kemiskinan di Indonesia pada September 2020 mencapai 27,55 juta orang. Dibandingkan Maret 2020, Tingkat Kemiskinan meningkat 1,13 juta orang. Sementara jika dibandingkan dengan September 2019, Tingkat Kemiskinan meningkat sebanyak 2,76 juta orang (Arfah et al., 2020)

Secara absolut, Tingkat Kemiskinan di Indonesia masih cukup tinggi. Dari jumlah tersebut, sebanyak 61,32 persen diantaranya bertempat tinggal di wilayah perdesaan dan umumnya bekerja pada sektor pertanian. Hal ini menunjukkan bahwa masalah kemiskinan di Indonesia merupakan permasalahan yang dominan di daerah perdesaan. Faktor pertama yang mempengaruhi persentase kemiskinan adalah jumlah penduduk yang besar apabila diikuti dengan kualitas yang memadai merupakan modal pembangunan yang handal, namun apabila kualitas rendah justru akan menjadi beban pembangunan. Mereka tidak mempunyai lahan atau alat produksi sendiri biasanya merupakan korban pertama dari langkah-langkah penghematan anggaran Pemerintah (Rachmawati, 2020). Oleh karena itu diperlukan suatu strategi penanggulangan kemiskinan yang terpadu, terintegrasi dan sinergis sehingga dapat menyelesaikan masalah secara tuntas. Persentase penduduk yang hidup di bawah garis kemiskinan juga harus digunakan sebagai salah satu alat untuk mengukur tingkat ketimpangan ekonomi antar daerah. Sebab kemiskinan adalah karena kurangnya pendapatan dan aset untuk memenuhi kebutuhan dasar seperti makanan, pakaian, perumahan dan tingkat kesehatan dan pendidikan, selain itu kemiskinan juga berkaitan dengan keterbatasan lapangan pekerjaan dan biasanya mereka yang dikategorikan miskin tidak memiliki pekerjaan atau pengangguran. Serta masalah-masalah lainnya yang secara eksplisit berkaitan erat dengan masalah kemiskinan. Baik Pemerintah Pusat maupun Daerah telah berupaya dalam melaksanakan berbagai kebijakan dan program-program penanggulangan kemiskinan namun masih jauh dari induk permasalahan kebijakan dan program yang dilaksanakan belum menampakkan hasil yang optimal (Perpres No. 166 Tahun 2014, 2014). Masih terjadi kesenjangan antara rencana dengan pencapaian tujuan karena kebijakan dan program penanggulangan kemiskinan lebih berorientasi pada program sektoral. Seseorang atau kelompok orang yang tidak mampu menyelenggarakan hidupnya sampai suatu taraf yang dianggap manusiawi (www.bbc.com, 2014). Kemiskinan meliputi dimensi politik, sosial budaya dan psikologi, ekonomi dan akses terhadap asset, dimensi tersebut saling terkait dan saling mengunci/membatasi. Kemiskinan adalah ketidakberdayaan, terpinggirkannya dan tidak memiliki rasa bebas. Faktor yang mempengaruhi Tingkat Kemiskinan adalah pertumbuhan ekonomi.

Menurut (Raišienė et al., 2014; Wang et al., 2019) bahwa upaya menurunkan tingkat pengangguran dan tingkat kemiskinan adalah sama pentingnya. Secara teori, jika masyarakat tidak menganggur berarti mempunyai pekerjaan dan penghasilan, dan dengan penghasilan tersebut diharapkan dapat memenuhi kebutuhan hidup. Jika kebutuhan hidup terpenuhi, maka tidak akan ada miskin. Sehingga dikatakan dengan tingkat pengangguran rendah maka Tingkat Kemiskinan juga rendah. Faktor yang mempengaruhi perluasan kesempatan kerja antara lain : perkembangan jumlah penduduk dan angkatan kerja, pertumbuhan ekonomi dan kebijakan mengenai perluasan kesempatan kerja itu sendiri. Tenaga kerja merupakan salah satu faktor produksi yang sangat penting disamping sumber alam, modal dan teknologi ( $R$ et al., 2013). Tenaga kerja mempunyai peranan yang sangat penting dalam pembangunan, sebagai pelaku pembangunan. Masalah ketenagakerjaan merupakan masalah yang begitu nyata dan dekat dengan lingkungan, bahkan masalah ketenagakerjaan dapat menimbulkan masalah baru baik di bidang ekonomi maupun non-ekonomi. Tingkat pengangguran yang tinggi menyebabkan rendahnya pendapatan yang selanjutnya memicu munculnya kemiskinan. Pertumbuhan ekonomi digunakan untuk memahami dinamika perekonomian suatu wilayah dengan melihat percepatan perekonomiannya. Hal ini menunjukkan bahwa dengan peningkatan pertumbuhan ekonomi mengindikasikan adanya kenaikan permintaan akan barang dan jasa, artinya kebutuhan masyarakat akan barang dan jasa akan meningkat, sehingga secara tidak langsung dengan 
peningkatan pertumbuhan ekonomi mampu mengurangkan kemiskinan yang selalu diidentikkan dengan tidak mampunyai masyarakat dalam pemenuhan kebutuhan. Dapat dikatakan bahwa ketika perekonomian suatu daerah mengalami peningkatan maka Tingkat Kemiskinan akan mengalami penurunan (LeBaron, 2014).

Berdasarkan data Badan Pusat Statistik Perkembangan Tingkat Kemiskinan, Pengangguran, IPM dan PDRB Kabupaten Luwu Timur tahun 2010-2020, persentase penduduk miskin Kabupaten Luwu Timur pada tahun 2010 mencapai 9,18 persen atau 22,40 ribu jiwa, sementara jumlah pengangguran sebanyak 16.139 jiwa. Pada tahun 2011, persentase penduduk miskin mengalami penurunan menjadi 8,29 persen atau 20,40 ribu jiwa dan jumlah pengangguran menurun menjadi 8,005 jiwa. Kemudian pada tahun 2012, persentase penduduk miskin mengalami penurunan menjadi 7,71 persen atau 19,68 ribu jiwa, namun jumlah pengangguran meningkat menjadi 8,990 jiwa. Berdasarkan teori yang mengatakan jika tingkat pengangguran naik maka akan memicu jumlah kemiskinan bertambah namun, jumlah data tidak sesuai dalam teori yang dikemukakan. Selanjutnya pada tahun 2013 persentase penduduk miskin mengalami peningkatan menjadi 8,38 persen atau 22,20 ribu jiwa, tetapi sebaliknya jumlah pengangguran mengalami penurunan menjadi 7,027 jiwa. Pada tahun 2014 persentase penduduk miskin kembali mengalami penurunan menjadi 7,67 persen atau 20,78 ribu jiwa, namun jumlah pengangguran kembali meningkat menjadi 9,962 jiwa. Tahun 2015 persentase penduduk miskin dan jumlah pengangguran mengalami penurunan menjadi 7,18 persen atau 19,70 ribu jiwa penduduk miskin dan 7,026 jiwa pengangguran. Pada periode tahun 2016 dan 2017 persentase penduduk miskin mengalami peningkatan menjadi 7,52 persen atau 21,08 ribu jiwa dan 7,66 persen atau 21,90 ribu jiwa, sementara jumlah pengangguran tahun 2016 menurun menjadi 6,801 jiwa dan di tahun 2017 terus menurun menjadi 3,572 jiwa. Sementara pada periode tahun 2018 persentase penduduk miskin kembali mengalami penurunan menjadi 7,23 persen atau 21,15 ribu jiwa dan tahun 2019 persentase penduduk miskin kembali mengalami penurunan menjadi 6,98 atau 20,83 ribu jiwa, sementara jumlah pengangguran di tahun 2018 mengalami penurunan menjadi 3.060 jiwa dan kembali meningkat di tahun 2019 menjadi 5.476 jiwa. Pada tahun 2020, persentase penduduk miskin kembali mengalami penurunan menjadi 6,85 persen atau 20,82 ribu jiwa, sementara jumlah pengangguran mengalami peningkatan menjadi 7.029 jiwa. Dapat di lihat bahwa data tingkat kemiskinan dan jumlah pengangguran pada periode tahun 2010 sampai dengan tahun 2020 cenderung bersifat fluktuatif.

Dari data tersebut menunjukkan bahwa IPM setiap tahunnya mengalami peningkatan 4,75 poin dari tahun 2010 sebesar 68,94 poin sampai dengan tahun 2020 menjadi 73,22 poin dan Tingkat Kemiskinan pada periode yang sama mengalami fluktuasi walaupun secara akumulasi pada tahun 2020 mengalami penurunan menjadi 6,85 persen atau 20,82 ribu jiwa dari tahun 2010 sebesar 9,18 persen atau 22,40 ribu jiwa. Berdasarkan teori, rendahnya Indeks Pembangunan Manusia (IPM) berakibat pada rendahnya produktivitas kerja dari penduduk. Rendahnya produktivitas berakibat pada rendahnya perolehan pendapatan. Sehingga dengan rendahnya pendapatan menyebabkan tingginya Tingkat Kemiskinan. Namun kenyataannya setiap tahunnya tidak sesuai dengan teori yang dikemukakan. Demikian pula dengan perkembangan PDRB yang setiap tahunnya cenderung mengalami peningkatan tetapi kenyataannya juga jumlah penduduk miskin tidak menurun secara signifikan sesuai dalam teori yang di kemukakan. Seperti yang terlihat pada data PDRB di tahun 2013 yang meningkat mencapai 16,66 Triliun Rupiah namun Tingkat Kemiskinan semakin meningkat menjadi 8,38 persen atau 22,20 jiwa. Begitupun beberapa data pada tahun-tahun yang lain terlihat saling bertolak belakang capaiannya.

Dari uraian diatas menggambarkan dengan capaian Indeks Pembangunan Manusia Kabupaten Luwu Timur yang berkategori tinggi selama kurun waktu 11 tahun terakhir, idealnya mampu menekan angka kemiskinan di Kabupaten Luwu Timur jauh lebih rendah dari apa yang telah dicapai saat ini. Menurut Halvarsson et al (2018) menyatakan pembangunan manusia di Indonesia adalah identik dengan pengurangan kemiskinan. Investasi di bidang pendidikan dan kesehatan akan lebih berarti bagi penduduk miskin dibandingkan penduduk tidak miskin, karena aset utama penduduk miskin adalah tenaga kasar mereka. Tersedianya fasilitas pendidikan dan kesehatan murah akan sangat membantu untuk meningkatkan produktivitas masyarakat dan pada gilirannya akan meningkatkan pendapatan masyarakat tersebut.

Begitupun dengan capaian PDRB Kabupaten Luwu Timur pada periode 11 tahun terakhir yang terus mengalami peningkatan, namun belum dapat berdampak langsung terhadap penurunan angka 
kemiskinan (de Gregori \& Kuznets, 1967), pertumbuhan dan kemiskinan mempunyai korelasi yang sangat kuat, karena pada tahap awal proses pembangunan tingkat kemiskinan cenderung meningkat dan pada saat mendekati tahap akhir pembangunan jumlah orang miskin berangsur-angsur berkurang. Hal yang menarik dan terkesan kontradiksi dengan teori-teori hubungan antara pengangguran dan kemiskinan ditunjukkan data pengangguran dan kemiskinan di Kabupaten Luwu Timur dalam kurun waktu 11 tahun. Dimana pada tahun 2012, 2014, 2019 dan 2020 terjadi peningkatan angka pengangguran namun terjadi penurunan tingkat kemiskinan. Secara teori, jika masyarakat tidak menganggur berarti mempunyai pekerjaan dan penghasilan, dan dengan penghasilan tersebut diharapkan dapat memenuhi kebutuhan hidup. Jika kebutuhan hidup terpenuhi, maka tidak akan ada miskin. Sehingga dapat dikatakan, dengan tingkat pengangguran rendah maka Tingkat Kemiskinan juga rendah. Sebaliknya jika tingkat pengangguran tinggi akan menyebabkan rendahnya pendapatan yang selanjutnya memicu munculnya kemiskinan.

Tabel 1: Rumusan dan Tujuan Penelitian

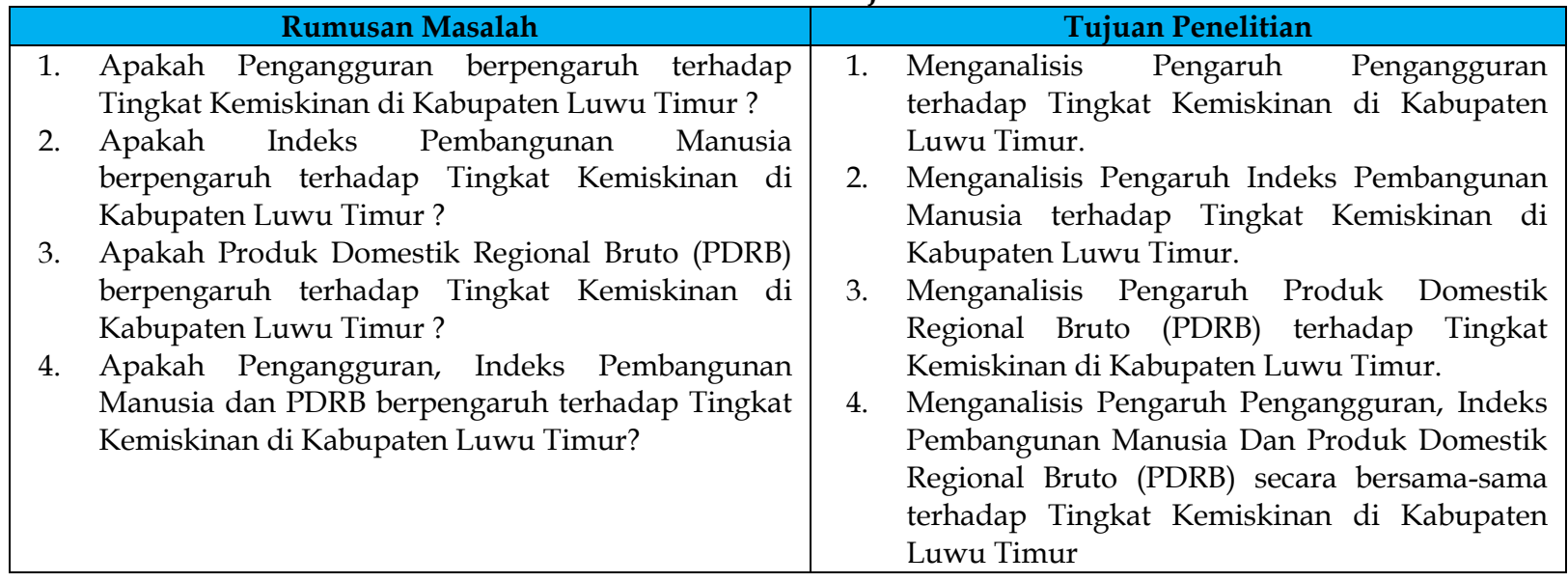

\section{Tinjauan Pustaka}

Dalam melakukan Penelitian ini, Penulis memiliki beberapa referensi dari penelitian terdahulu yang telah ada. Beberapa penelitian terdahulu yang menjadi referensi diantaranya adalah sebagai berikut: (1) Prasetyoningrum \& Sukmawati (2018) melakukan penelitian yang berjudul "Analisis Pengaruh Indeks Pembangunan Manusia (IPM), Pertumbuhan Ekonomi dan Pengagguran Terhadap Kemiskinan di Indonesia". Penelitian ini bertujuan untuk mengetahui pengaruh indeks pembangunan manusia (IPM), tingkat pengangguran, dan pertumbuhan ekonomi secara langsung terhadap tingkat kemiskinan. Selanjutnya, akan dilihat pula pengaruh tidak langsung IPM dan pertumbuhan ekonomi melalui pengangguran dalam mempengaruhi tingkat kemiskinan. Penelitian ini merupakan penelitian kuantitatif menggunakan data sekunder yang berasal dari BPS dengan data panel yang merupakan data time series periode 2013-2017 dan data cross section dari 33 Provinsi di Indonesia. Pengolahan datanya menggunakan metode analisis jalur menggunakan software WarpPLS 5.0. Hasil penelitian ini menunjukkan bahwa IPM berpengaruh secara langsung dan negatif terhadap tingkat kemiskinan dengan nilai koefisien jalur -0.71. Sedangkan pertumbuhan ekonomi tidak berpengaruh secara signifikan terhadap penurunan tingkat kemiskinan dengan nilai probabilitas 0.23 . Kemudian, tampak pula bahwa pengangguran berpengaruh positif terhadap tingkat kemiskinan dengan nilai koefisien jalur 0.14 dan berpengaruh signifikan dengan probabilitas 0.0035 . Penelitian ini juga menunjukkan bahwa pengangguran dapat memediasi antara IPM dengan kemiskinan. Selain itu, pengangguran juga dapat memediasi antara pertumbuhan ekonomi dengan kemiskinan. (2) Leonita \& Sari (2019) melakukan penelitian yang berjudul "Pengaruh PDRB, Pengangguran dan Pembangunan Manusia Terhadap Kemiskinan di Indonesia". Studi ini bertujuan memverifikasi apakah produk domestik regional bruto, tingkat pengangguran, dan IPM memberikan kontribusi pada kemiskinan pada 34 Provinsi di Indonesia selama periode 2011-2017. Penelitian ini bersifat asosiatif karena bertujuan untuk menguji pengaruh antar variable penelitian. Data penelitian diambil dari situs online Badan Pusat Statistik (BPS) Indonesia. Metode regresi dengan data panel dilakukan dengan menggunakan aplikasi E-views. Hasil uji chow dan hausman menyimpulkan model efek tetaplah yang digunakan. 
Hasil penelitian menunjukkan laju PDRB, IPM, dan pengangguran secara simultan memberikan pengaruh pada kemiskinan. Pengujian secara parsial menunjukkan tingkat kemiskinan dipengaruhi oleh laju PDRB dan pengangguran. Sedangkan IPM tidak berpengaruh terhadap kemiskinan. Pemerintah diharapkan fokus dalam meningkatkan pendapatan daerah. Dengan pendapatan daerah meningkat, maka diharapkan pengangguran berkurang dan tingkat kemiskinan juga berkurang. IPM juga tentunya memiliki peran dalam meningkatkan pendapatan daerah karena dengan membangun manusia yang baik diharapkan akan meningkatkan standar hidup masyarakat. (3) Suripto \& Subayil (2020) melakukan penelitian yang berjudul "Pengaruh Tingkat Pendidikan, Pengangguran, Pertumbuhan Ekonomi dan Indeks Pembangunan Manusia Terhadap Kemiskinan di D.I. Yogyakarta Periode 2010-2017". Penelitian ini menggunakan data sekunder dengan alat analisis data panel, yang terdiri dari data deret waktu selama periode 2010-2017 dan data cross section 5 Kabupaten/Kota di Provinsi Daerah Istimewa Yogyakarta. Model analisis yang digunakan dalam penelitian ini untuk mengestimasi model regresi data panel adalah dengan menggunakan model efek tetap. Hasil dalam penelitian dengan tingkat signifikansi 5\% menunjukkan bahwa (1) Variabel Tingkat Pendidikan tidak berpengaruh signifikan terhadap kemiskinan; (2) variabel pengangguran tidak berpengaruh terhadap kemiskinan; (3) Variabel Pertumbuhan Ekonomi memiliki pengaruh negatif dan signifikan terhadap kemiskinan; (4) Variabel Indeks Pembangunan Manusia memiliki pengaruh negatif dan signifikan terhadap kemiskinan. (4) Dinata (2020) melakukan penelitian yang berjudul "Pengaruh Indeks Pembangunan Manusia, Pertumbuhan Ekonomi, Jumlah Penduduk dan Tingkat Pengangguran Terhadap Kemiskinan di Provinsi Riau Tahun 2003-2018". Penelitian ini dilakukan di Provinsi Riau dan merupakan penelitian kuantitatif dengan menggunakan data sekunder yang diperoleh dari BPS Provinsi Riau. Penelitian ini dilaksanakan dengan pendekatan analisis regresi linier berganda. Menggunakan data time series periode 2003-2018. Pengolahan data menggunakan software SPSS. Dari penelitian yang telah dilakukan, maka diperoleh hasil Indeks Pembangunan Manusia berpengaruh negatif dan signifikan terhadap kemiskinan dengan nilai -0.172. Kemudian Pertumbuhan Ekonomi tidak berpengaruh signifikan terhadap kemiskinan dengan nilai -0.013 . Jumlah Penduduk berpengaruh negatif signifikan terhadap kemiskinan dengan nilai $-2.472 \mathrm{E}-6$ dan Tingkat Pengangguran tidak berpengaruh signifikan terhadap kemiskinan dengan nilai 0.028. Penelitian ini juga memperoleh hasil dari keempat variabel yakni Indeks Pembangunan Manusia, Pertumbuhan Ekonomi, Jumlah Penduduk dan Tingkat Pengangguran secara bersama-sama berpengaruh signifikan terhadap kemiskinan. Kemudian sumbangan pengaruh dari keempat variabel tersebut adalah 95.1\%, sedangkan sisanya dipengaruhi oleh variabel lain.

\section{A. Kerangka Konseptual}

Dari penjelasan di atas dapat digambarkan Pengaruh Pengangguran, Indeks Pembangunan Manusia, dan PDRB Terhadap Tingkat Kemiskinan Di Kabupaten Luwu Timur dalam suatu kerangka pemikiran seperti berikut:



Gambar 2. Kerangka Konseptual

Berdasarkan rumusan masalah dan kerangka konseptual tersebut di atas, maka hipotesis, yang diajukan dalam penelitian ini adalah: 
1. Pengangguran Berpengaruh Positif dan Signifikan terhadap Tingkat Kemiskinan di Kabupaten Luwu Timur.

2. Indeks Pembangunan Manusia Berpengaruh Positif dan Signifikan terhadap Tingkat Kemiskinan di Kabupaten Luwu Timur.

3. PDRB Berpengaruh Positif dan Signifikan terhadap Tingkat Kemiskinan di Kabupaten Luwu Timur.

\title{
3. Metode Penelitian
}

Metode penelitian merupakan suatu cara untuk dapat memahami suatu objek penelitian dengan memandu peneliti dengan urutan-urutan bagaimana penelitian dilakukan yang meliputi teknik dan prosedur yang digunakan dalam penelitian. Dalam penelitian ini pendekatan yang digunakan oleh Peneliti adalah penelitian kuantitatif dan menggunakan rumus statistik untuk membantu menganalisa data dan fakta yang diperoleh. Sugiyono (2010) menjelaskan bahwa pendekatan kuantitatif adalah penelitian yang analisisnya lebih fokus pada data-data numerikal (angka) yang diolah dengan menggunakan metode statistika. Lokasi penelitian dilakukan di Kabupaten Luwu Timur dan dilakukan pada Bulan Maret sampai dengan Bulan Mei Tahun 2021. Jenis data yang digunakan dalam penelitian ini adalah data sekunder.. Data-data yang diperlukan di dalam penelitian ini sebagian besar diperoleh dari Website dan Katalog Badan Pusat Statistik Kabupaten Luwu Timur. Jadi populasi dalam penelitian ini adalah data Pengangguran, Indeks Pembangunan Manusia, PDRB dan data Kemiskinan yang diambil dari Badan Pusat Statistik (BPS) Kabupaten Luwu Timur. Sampel yang diambil dalam penelitian ini adalah data Pengangguran, Indeks Pembangunan Manusia, PDRB dan Tingkat Kemiskinan di Kabupaten Luwu Timur pada periode tahun 2010 sampai dengan tahun 2020. Metode Analisis Data yang digunakan pada penelitian ini adalah Analisis Statistik Deskriptif dan Analisis Statistik Inferensial. Statistik Deskriftif adalah statistik yang digunakan untuk menganalisa data dengan cara mendeskripsikan atau menggambarkan data yang telah terkumpul sebagaimana adanya tanpa bermaksud membuat kesimpulan yang berlaku umum atau generalisasi. Tahapan pengujian hipotesis menggunakan regresi linear berganda ditempuh dengan langkah menentukan persamaan regresinya adalah :

\author{
Dimana : \\ $\mathrm{Y}=$ Kemiskinan \\ bo $=$ Konstanta \\ $\mathrm{b} 1=$ Koefisien $\mathrm{X} 1$ \\ $\mathrm{b} 2=$ Koefisien $\mathrm{X} 2$ \\ b3 = Koefisien X3 \\ $\mathrm{X} 1$ = Variabel Pengangguran \\ $\mathrm{X} 2=$ Variabel Indeks Pembangunan Manusia \\ $\mathrm{X} 3$ = Variabel PDRB \\ $\mathrm{e}=$ Error term
}

Untuk mengetahui tingkat signifikan dari masing-masing koefisien regresi variabel independen (variabel bebas) terhadap variabel dependen (variabel terikat). Uji Signifikan merupakan prosedur yang digunakan untuk menguji kebenaran atau kesalahan dari hasil hipotesis nol dari sampel, ide dasar yang melatar belakangi pengujian signifikansi adalah uji statistic (estimator) dari distribusi sampel dari suatu statistik di bawah hipotesis nol. Keputusan untuk mengolah H0 dibuat berdasarkan nilai uji statistik yang diperoleh dari data yang ada. Uji statistik terdiri dari pengujian koefisien regresi parsial (uji t), pengujian koefisien regresi secara bersama-sama (uji F), dan pengujian koefisien determinasi Goodness of fit test $\left(\mathrm{R}^{2}\right)$.

(2) Uji Koefisien Determinasi (R2), koefisien determinasi bertujuan untuk mengukur seberapa jauh Tingkat Kemiskinan dapat menjelaskan variasi variabel dependen. Pada pengujian hipotesis pertama koefisien determinasi dilihat dari besarnya nilai (Adjusted $\mathrm{R}^{2}$ ) untuk mengetahui seberapa jauh variabel bebas yaitu Pengangguran, IPM dan PDRB terhadap Tingkat Kemiskinan. Nilai (Adjusted R2) mempunyai interval antar 0 dan 1. Jika nilai Adjusted $\mathrm{R}^{2}$ bernilai besar (mendekati 1) 
berarti variabel bebas dapat memberikan hampir semua informasi yang dibutuhkan untuk memprediksi variabel dependen. Sedangkan jika (Adjusted R2) bernilai kecil berarti kemampuan variabel bebas dalam menjelaskan variabel dependen sangat terbatas. Secara umum koefisien determinasi untuk data silang (crossection) relatif rendah karena adanya variasi yang besar antara masing-masing pengamatan, sedangkan untuk data runtun biasanya mempunyai nilai koefisiean determinasi yang tinggi. Uji Parsial $(t)$, uji ini digunakan untuk mengetahui apakah masing-masing variabel independen secara sendiri-sendiri mempunyai pengaruh secara signifikan terhadap variabel dependen. Dengan kata lain, untuk mengetahui apakah masing-masing variabel independen dapat menjelaskan perubahan yang terjadi pada variabel dependen secara nyata. Untuk mengkaji pengaruh variabel independen terhadap dependen secara individu dapat dilihat hipotesis berikut :

$\mathrm{H} 0: \beta 1=0$ artinya tidak berpengaruh,

$\mathrm{H} 1: \beta 1>0$ artinya berpengaruh positif,

$\mathrm{H} 1: \beta 1<0$ artinya berpengaruh negatif.

Dimana $\beta 1$ Koefisien variabel independen ke-1 yaitu nilai parameter hipotesis. Biasanya nilai $\beta$ dianggap nol, artinya tidak ada pengaruh variabel X1 terhadap Y. Uji Simultan (Uji F), uji f-statistik ini adalah pengujian yang bertujuan untuk mengetahui seberapa besar pengaruh koefisien regresi secara bersama-sama terhadap variabel dependen. Untuk mengetahui signifikan tidaknya, maka derajat signifikan yang digunakan sebesar $5 \%$ atau $(\alpha=0,05)$. Apabila nilai $\mathrm{F}$ hasil perhitungan lebih besar dari pada nilai $\mathrm{F}$ menurut tabel maka hipotesis alternatif variabel independen berpengaruh signifikan terhadap variabel dependen. Dengan tingkat signifikan (a) yang digunakan adalah 5\% distribusi F dengan derajat kebebasan $(\alpha ; \mathrm{K}-1, \mathrm{n}-\mathrm{k})$. Kriteria Pengujian : F hitung $<\mathrm{F}$ tabel $=$ diterima, artinya variabel independen secara serentak atau bersamaan tidak mempengaruhi variabel dependen secara signifikan. $\mathrm{F}$ hitung $>\mathrm{F}$ tabel $=$ Ho ditolak, artinya variabel independen secara serentak atau bersama-sama mempengaruhi variabel dependen secara signifikan. Uji Asumsi Klasik, uji ini dilakukan untuk mengetahui bahwa data yang diolah adalah sah (tidak terdapat penyimpangan) serta distribusi normal, maka data tersebut akan diuji melalui uji asumsi klasik, yaitu: (a) Uji Normalitas, uji Normalitas bertujuan untuk menguji apakah dalam suatu model regresi linear variabel terikat dan variabel bebas keduanya Berdistribusi Normal atau tidak. Model regresi yang baik adalah data yang Berdistribusi Normal. Dalam penelitian ini, untuk mendeteksi normalitas data dilakukan dengan pengujian Kolmogorov Smirnov. Uji Multikolineritas, uji Multikolineritas bertujuan untuk mengetahui ada atau tidaknya hubungan linear yang sempurna diantara variabel-variabel bebas dalam model regresi. Adanya Multikolinearitas dapat dilihat dari Tolerance Value atau Nilai Variance Inflation Factor (VIF). Batas Tolerance Value 0,1 batas VIF adalah 5. Apabila Tolerance Value $<0,1$ atau VIF $>5$ maka terjadi multikolinieritas. Tetapi jika Tolerance value $>0,1$ atau VIF $<5$ maka tidak terjadi multikolinieritas. (c) Uji Heteroskedastisitas, menurut Imam Ghozali (2016) Uji Heteroskedastisitas bertujuan menguji apakah dalam model regresi terdapat ketidaksamaan variabel dan residual atau pengamatan ke pengamatan lain. Konsekuensinya adanya Heteroskedastisitas dalam model regresi adalah penakir yang diperoleh tidak efisien, baik dalam sampel kecil maupun besar. Untuk mengetahui ada tidaknya heteroskedastisitas juga dapat diketahui dengan melakukan Uji Glejser. Jika variabel bebas signifikan secara statistik mempengaruhi variabel terikat, maka ada indikasi terjadi Heteroskedastisitas. (d) Uji Autokorelasi, uji Autokorelasi bertujuan untuk menguji apakah dalam suatu model regresi linear ada korelasi antara kesalahan pada Periode $t$ (tahun sekarang) dengan Periode t-1 (tahun sebelumnya). Jika terjadi korelasi, maka dinamakan ada problem autokorelasi. Untuk menguji ada tidaknya gejala autokorelasi maka dapat di deteksi dengan Uji Durbin-Watson. Pengambilan keputusan ada tidaknya Autokorelasi adalah sebagai berikut: Angka DW di bawah -2 berarti Ada Autokorelasi Positif, Angka D-W diantar -2 sampai +2 berarti Tidak Ada Autokorelasi, Angka D-W di atas +2 berarti Ada Autokorelasi Negatif.

\section{Pembahasan}

a) Deskripsi Variabel Penelitian

Subyek penelitian yang dibahas ini adalah bagaimana pengaruh Pengangguran, Indeks Pembangunan Manusia dan PDRB terhadap Tingkat Kemiskinan di Kabupaten Luwu Timur, dimana 
objek data yang digunakan berasal dari Badan Pusat Statistik (BPS) Kabupaten Luwu Timur dan Provinsi Sulawesi Selatan. Data Pengangguran, Indeks Pembangunan Manusia dan PDRB sebagai variabel Independen yang digunakan untuk melihat bagaimana variabel independen tersebut mempengaruhi Tingkat Kemiskinan di Kabupaten Luwu Timur sebagai variabel dependen. Adapun data-data variabel yang digunakan dalam penelitian ini adalah data dalam kurun waktu tahun 2010 sampai dengan tahun 2020 (11 tahun). Untuk mendukung hasil penelitian, data penelitian yang diperoleh akan di analisis dengan Model Regresi Linear Berganda karena variabel independen yang digunakan terdiri dari 3 (tiga) variabel. Model Regresi Linear Berganda digunakan untuk menguji bagaimana hubungan variabel independen dengan variabel dependen. Selanjutnya akan dijelaskan dan diuraikan kondisi variabel dependen dan variabel independen di Kabupaten Luwu Timur yang dibahas dalam penelitian ini, yang terdiri dari :

\section{Variabel Tingkat Kemiskinan}

Secara umum, konsep kemiskinan dapat dibedakan ke dalam dua jenis yaitu kemiskinan absolut dan kemiskinan relatif. Kemiskinan absolut adalah kondisi ketidakmampuan seseorang untuk memenuhi kebutuhan pokok minimum seperti pangan, sandang, kesehatan, perumahan, dan pendidikan. Sedangkan kemiskinan relatif adalah kondisi yang disebabkan oleh pengaruh kebijakan pembangunan yang belum mampu menjangkau seluruh lapisan masyarakat sehingga menyebabkan seseorang lebih miskin dibandingkan dengan lainnya. Pemerintah Kabupaten Luwu Timur dalam kurun waktu 11 tahun terakhir telah mengalokasikan anggaran yang cukup besar untuk melaksanakan program-program pembangunan yang tujuan utamanya adalah penanggulangan kemiskinan dan peningkatan kesejahteraan masyarakat. Berikut disajikan perkembangan Tingkat Kemiskinan di Kabupaten Luwu Timur dalam kurun waktu tahun 2010 sampai dengan tahun 2020 :

Tabel 2. Jumlah dan Persentase Penduduk Miskin Kabupaten Luwu Timur Tahun 2010-2020

\begin{tabular}{|c|c|c|}
\hline \multirow{2}{*}{ TAHUN } & PENDUDUK MISKIN \\
\cline { 2 - 3 } & (Dalam Ribu Jiwa) & (\%) \\
\hline 2010 & 22.40 & 9,18 \\
\hline 2011 & 20,40 & 7,29 \\
\hline 2012 & 19,68 & 8,38 \\
\hline 2013 & 22,20 & 7,67 \\
\hline 2014 & 20,78 & 7,18 \\
\hline 2015 & 19,70 & 7,52 \\
\hline 2016 & 21,08 & 7,66 \\
\hline 2017 & 21,90 & 7,23 \\
\hline 2018 & 21,15 & 6,98 \\
\hline 2019 & 20,83 & 6,85 \\
\hline 2020 & 20,82 & \\
\hline
\end{tabular}

Sumber : Badan Pusat Statistik Kabupaten Luwu Timur, 2021.

Berdasarkan Tabel 2, pada tahun 2010 jumlah penduduk miskin Kabupaten Luwu Timur sebanyak 22,40 ribu jiwa atau sebesar 9,18 persen dan menurun pada tahun 2011 mencapai 8,29 persen atau 20,40 ribu jiwa. Pada tahun 2012, persentase penduduk miskin kembali mengalami penurunan menjadi 7,71 persen atau 19,68 ribu jiwa. Selanjutnya pada tahun 2013 persentase penduduk miskin mengalami peningkatan menjadi 8,38 persen atau 22,20 ribu jiwa. Pada tahun 2014 persentase penduduk miskin kembali mengalami penurunan menjadi 7,67 persen atau 20,78 ribu jiwa. Tahun 2015 persentase penduduk miskin terus mengalami penurunan menjadi 7,18 persen atau 19,70 ribu jiwa penduduk miskin. Pada periode tahun 2016 dan 2017 persentase penduduk miskin mengalami peningkatan menjadi 7,52 persen atau 21,08 ribu jiwa dan 7,66 persen atau 21,90 ribu jiwa. Sementara pada periode tahun 2018 persentase penduduk miskin kembali mengalami penurunan menjadi 7,23 persen atau 21,15 ribu jiwa dan di tahun 2019 persentase penduduk miskin kembali mengalami penurunan menjadi 6,98 atau 20,83 ribu jiwa. Pada tahun 2020, persentase penduduk miskin kembali mengalami penurunan menjadi 6,85 persen atau 20,82 ribu jiwa. Dapat di lihat bahwa data tingkat kemiskinan pada periode tahun 2010 sampai dengan tahun 2020 bersifat fluktuatif, dimana dari persentase penduduk miskin dan jumlah penduduk miskin cenderung mengalami penurunan. 


\section{Variabel Pengangguran}

Menurut Sukirno (2010) bahwa pengangguran merupakan suatu keadaan dimana seseorang yang tergolong dalam angkatan kerja ingin mendapatkan pekerjaan tetapi mereka belum dapat memperoleh pekerjaan tersebut. Penduduk usia kerja merupakan semua orang yang berumur 15 tahun ke atas. Pada usia ini, mereka memiliki potensi untuk masuk ke angkatan kerja dan pasar kerja. Penduduk usia kerja mengalami kenaikan dari 212,9 ribu orang pada tahun 2019 menjadi 217,7 ribu orang pada tahun 2020. Penduduk usia kerja mengalami tren yang cenderung meningkat seiring dengan bertambahnya jumlah penduduk di Kabupaten Luwu Timur. Sebagian besar penduduk usia kerja yaitu 72,36 persen atau 157,5 ribu orang merupakan angkatan kerja, terdiri dari 150,4 ribu orang penduduk bekerja dan 7.029 orang pengangguran. Jumlah angkatan kerja pada tahun 2020 mengalami peningkatan sebesar 13,8 ribu orang dibandingkan tahun 2019. Pada tahun 2020 Tingkat Partisipasi Angkatan Kerja (TPAK) meningkat menjadi 72,36 persen pada tahun 2020 dibandingkan tahun 2019 sebesar 67,48 persen. Peningkatan TPAK mengindikasikan bahwa terjadi peningkatan penduduk usia kerja yang aktif di pasar kerja baik menjadi penduduk bekerja maupun sebagai penganggur.

Salah satu bentuk penyerapan penduduk usia kerja di pasar kerja adalah bekerja, dimana dengan bekerja seseorang akan memperoleh atau membantu memperoleh pendapatan, keuntungan, maupun upah/gaji. Penduduk yang bekerja pada tahun 2020 sebanyak 150,4 ribu orang, mengalami peningkatan dibandingkan dengan tahun 2019 yang besarnya 138,2 ribu orang. Untuk melihat struktur penduduk bekerja, maka perlu diperhatikan karakteristiknya. Karakteristik penduduk bekerja akan disajikan berdasarkan lapangan pekerjaan utama, status pekerjaan utama, dan pendidikan tertinggi yang ditamatkan. Komposisi penduduk bekerja menurut lapangan pekerjaan utama dapat menggambarkan penyerapan masing-masing sektor dari seluruh penduduk yang bekerja di pasar kerja Kabupaten Luwu Timur. Berdasarkan hasil Sakernas Agustus 2020, dari tiga kategori lapangan pekerjaan, yang memiliki distribusi tenaga kerja paling banyak adalah sektor Pertanian sebesar 44,41 persen, sedangkan kategori manufaktur sebesar 18,13 persen dan kategori jasa sebesar 37,46 persen. Kategori lapangan pekerjaan yang mengalami peningkatan kontribusi jika dibandingkan dengan Agustus 2019 adalah kategori manufaktur sebesar 1,42 persen poin diikuti kategori pertanian sebesar 0,37 persen poin sedangkan kategori jasa mengalami penurunan sebesar 1,79 persen poin. Berdasarkan status pekerjaan utamanya, penduduk bekerja sebagai buruh/karyawan/pegawai pada Agustus 2020 masih mendominasi komposisi tenaga kerja di Indonesia yaitu sebesar 32,29 persen. Walaupun demikian, mengalami penurunan tertinggi yaitu sebesar 6,26 persen poin dibandingkan dengan Agustus 2019. Sedangkan status pekerjaan utama yang mengalami peningkatan tertinggi yaitu berusaha dibantu buruh tidak tetap meningkat 6,77 persen poin, dan pekerja keluarga/tak dibayar yang meningkat sebesar 2,39 persen poin. Berdasarkan status pekerjaan utama tersebut, penduduk bekerja dapat dikategorikan menjadi kegiatan formal dan informal. Penduduk yang bekerja di kegiatan formal mencakup mereka yang berusaha dengan dibantu buruh tetap dan buruh/karyawan/pegawai, sedangkan sisanya dikategorikan sebagai kegiatan informal (berusaha sendiri, berusaha dibantu buruh tidak tetap/buruh tidak dibayar, pekerja bebas, dan pekerja keluarga/tak dibayar). Pada Agustus 2020, penduduk yang bekerja di kegiatan informal sebanyak 98 ribu orang (65,14 persen), sedangkan yang bekerja di kegiatan formal sebanyak 52,5 ribu orang (34,86 persen). Penduduk bekerja di kegiatan informal pada Agustus 2020 mengalami peningkatan sebesar 7,29 persen poin dibandingkan dengan Agustus 2019.

Pendidikan merupakan salah satu indikasi terhadap kemampuan dan produktivitas tenaga kerja. Semakin tinggi pendidikan cenderung semakin tinggi juga keahlian dan produktivitas yang dimiliki. Saat ini, penduduk bekerja masih didominasi oleh mereka yang berpendidikan SD ke bawah yaitu sebanyak 35,44 persen pada Agustus 2020. Sedangkan tenaga kerja yang berpendidikan tinggi yaitu Diploma dan Universitas hanya sebesar 17,38 persen pada Agustus 2020. Dibandingkan dengan Agustus 2019, kontribusi pendidikan pada penduduk bekerja mengalami penurunan pada pendidikan SD ke bawah (0,76 persen poin) dan SMK (1,38 persen poin). Sedangkan penduduk bekerja dengan pendidikan SMP, SMA, Diploma I/II/III, dan Universitas mengalami peningkatan, dengan peningkatan terbesar pada pendidikan SMP sebesar 1,05 persen poin. Berikut disajikan perkembangan jumlah dan tingkat pengangguran di Kabupaten Luwu Timur dalam kurun waktu tahun 2010 sampai dengan tahun 2020 : 
Tabel 3. Jumlah dan Tingkat Pengangguran Kabupaten Luwu Timur Tahun 2010-2020

\begin{tabular}{|c|c|c|}
\hline \multirow{2}{*}{ TAHUN } & \multicolumn{2}{|c|}{ PENGANGGURAN } \\
\cline { 2 - 3 } & (Jiwa) & 13,22 \\
\hline 2010 & 16.139 & 7,16 \\
\hline 2011 & 8.005 & 8,12 \\
\hline 2012 & 8.990 & 6,28 \\
\hline 2013 & 7.027 & 8,10 \\
\hline 2014 & 9.962 & 5,37 \\
\hline 2015 & 7.026 & 4,10 \\
\hline 2016 & 6.801 & 2,58 \\
\hline 2017 & 3.572 & 2,03 \\
\hline 2018 & 3.060 & 3,81 \\
\hline 2019 & 5.476 & 4,46 \\
\hline 2020 & 7.029 & \\
\hline
\end{tabular}

Sumber : Badan Pusat Statistik Kabupaten Luwu Timur, 2021.

Berdasarkan Tabel 3, pada tahun 2010 pengangguran di Kabupaten Luwu Timur mencapai 16,139 jiwa atau 13,22 persen kemudian turun menjadi 8.005 jiwa atau 7,16 persen pada tahun 2011 . Selanjutnya pada tahun 2012 pengangguran kembali meningkat menjadi 8,990 jiwa atau 8,12 persen dan kembali menurun pada tahun 2013 menjadi 7,027 jiwa atau 6,28 persen. Pada tahun 2014 pengangguran kembali meningkat menjadi 9,962 jiwa atau 8,10 persen, namun mengalami penurunan pada tahun 2015 menjadi 7.026 jiwa atau 5,37 persen. Pada periode tahun 2016 sampai dengan tahun 2018 pengangguran makin menurun menjadi 6.801 jiwa atau 4,10 persen di tahun 2016, 3,572 jiwa atau 2,58 persen di tahun 2017 dan 3.060 jiwa atau 2,03 persen. Pada tahun 2019 pengangguran kembali mengalami peningkatan menjadi 5.476 jiwa atau 3,81 persen dan di tahun 2020 terus meningkat menjadi 7.029 jiwa atau 4,46 persen. Dapat dilihat bahwa data jumlah pengangguran pada periode tahun 2010 sampai dengan tahun 2020 juga bersifat fluktuatif dan cenderung mengalami peningkatan.

\section{Variabel Indeks Pembangunan Manusia}

Indeks Pembangunan Manusia (IPM), atau dikenal dengan sebutan Human Development Indeks (HDI) adalah merupakan indikator capaian pembangunan kualitas hidup masyarakat yang disusun berdasarkan tiga dimensi dasar, yaitu umur panjang dan hidup sehat, pengetahuan, dan standar hidup layak. Dimensi umur panjang dan hidup sehat diwakili oleh indikator umur harapan hidup saat lahir. Dimensi pengetahuan diwakili oleh indikator harapan lama sekolah dan rata-rata lama sekolah, sedangkan dimensi standar hidup layak diwakili oleh pengeluaran per kapita yang disesuaikan. Indeks Pembangunan Manusia Kabupaten Luwu Timur Tahun 2020 sebesar 73.22, menempati peringkat 4 di Provinsi Sulawesi Selatan. Pembangunan manusia di Kabupaten Luwu Timur sejak tahun 2016 sudah berstatus tinggi. Selama periode 2016-2020 angka IPM Kabupaten Luwu Timur selalu IPM Kabupaten Luwu Timur setiap tahun selalu mengalami peningkatan. Selain itu, juga selalu berada diatas IPM Provinsi Sulawesi Selatan. Berikut disajikan perkembangan Indeks Pembangunan Manusia Kabupaten Luwu Timur dalam kurun waktu tahun 2010 sampai dengan tahun 2020 :

Tabel 4. Indeks Pembangunan Manusia Kabupaten Luwu Timur Tahun 2010-2020

\begin{tabular}{|c|c|}
\hline TAHUN & $\begin{array}{c}\text { INDEKS PEMBANGUNAN MANUSIA } \\
\text { (Poin) }\end{array}$ \\
\hline 2010 & 68,47 \\
\hline 2011 & 68,94 \\
\hline 2012 & 69,34 \\
\hline 2013 & 69,53 \\
\hline 2014 & 69,75 \\
\hline 2015 & 70,43 \\
\hline 2016 & 70,95 \\
\hline 2017 & 71,46 \\
\hline 2018 & 72,16 \\
\hline 2019 & 72,80 \\
\hline
\end{tabular}

Sumber : Badan Pusat Statistik Kabupaten Luwu Timur, 2021. 
Pembangunan manusia di Kabupaten Luwu Timur memperlihatkan perkembangan yang baik dari tahun ke tahun. Perkembangan IPM menunjukkan semakin membaiknya pembangunan manusia secara umum di Kabupaten Luwu Timur. Dilihat dari trennya, IPM Kabupaten Luwu Timur mengalami peningkatan. Dalam 11 tahun terakhir (2010-2020), terjadi kenaikan 4,75 poin. Pertumbuhan IPM merupakan salah satu cara untuk melihat perkembangan pembangunan manusia di suatu wilayah. Pertumbuhan IPM di Kabupaten Luwu Timur cenderung berfluktuasi setiap tahunnya. Pada periode tahun 2010-2020, pembangunan manusia di Kabupaten Luwu Timur mengalami pertumbuhan sebesar 6,94 persen. Pertumbuhan IPM tertinggi terjadi pada periode tahun 2017-2018 yang mencapai 0,98 persen, sementara pertumbuhan terendah terjadi pada periode tahun 2012-2013 yang hanya mencapai 0,27 persen.

\section{Variabel PDRB}

Produk Domestik Regional Bruto (PDRB) merupakan nilai tambah bruto seluruh barang dan jasa yang tercipta atau dihasilkan di wilayah domestik suatu Negara yang timbul akibat berbagai aktivitas ekonomi dalam suatu periode tertentu tanpa memperhatikan apakah faktor produksi yang dimiliki residen atau non-residen. Penyusunan PDRB dapat dilakukan melalui 3 (tiga) pendekatan yaitu pendekatan produksi, pengeluaran, dan pendapatan yang disajikan atas dasar harga berlaku dan harga konstan. PDRB atas dasar harga berlaku atau dikenal dengan PDRB nominal disusun berdasarkan harga yang berlaku pada periode penghitungan, dan bertujuan untuk melihat struktur perekonomian. Sedangkan PDRB atas dasar harga konstan disusun berdasarkan harga pada tahun dasar dan bertujuan untuk mengukur pertumbuhan ekonomi. Besarnya peranan berbagai lapangan usaha ekonomi dalam memproduksi barang dan jasa sangat menentukan struktur ekonomi suatu daerah. Struktur ekonomi yang terbentuk dari nilai tambah yang diciptakan oleh setiap lapangan usaha menggambarkan seberapa besar ketergantungan suatu daerah terhadap kemampuan berproduksi dari setiap lapangan usaha. Berikut disajikan perkembangan Produk Domestik Regional Bruto Atas Dasar Harga Konstan Menurut Lapangan Usaha Kabupaten Luwu Timur dalam kurun waktu tahun 2010 sampai dengan tahun 2020 :

Tabel 5. Produk Domestik Regional Bruto (PDRB) Menurut Lapangan Usaha Atas Dasar Harga Berlaku Kabupaten Luwu Timur Tahun 2010-2020

\begin{tabular}{|c|c|}
\hline TAHUN & $\begin{array}{c}\text { PDRB } \\
\text { ATAS DASAR HARGA BERLAKU } \\
\text { (Triliun Rupiah) }\end{array}$ \\
\hline 2010 & 11,83 \\
\hline 2011 & 13,83 \\
\hline 2012 & 15,27 \\
\hline 2013 & 16,66 \\
\hline 2014 & 19,03 \\
\hline 2015 & 19,22 \\
\hline 2016 & 17,40 \\
\hline 2018 & 18,34 \\
\hline 2019 & 20,39 \\
\hline 2020 & 20,99 \\
\hline
\end{tabular}

Sumber : Badan Pusat Statistik Kabupaten Luwu Timur, 2021

Berdasarkan harga berlaku 2010, nilai PDRB Kabupaten Luwu Timur pada tahun 2010 sampai dengan tahun 2020 terus meningkat. Naiknya nilai PDRB ini dipengaruhi oleh meningkatnya produksi di seluruh lapangan usaha dan adanya inflasi. Nilai PDRB Kabupaten Luwu Timur pada tahun 2010 sebesar 11,83 Triliun Rupiah, kemudian naik di tahun 2011 mencapai 13,83 Triliun Rupiah dan kembali meningkat di tahun 2012 mencapai 15,27 Triliun Rupiah. Selanjutnya pada tahun 2013 Nilai PDRB Kabupaten Luwu Timur mencapai 16,66 Triliun Rupiah dan terus meningkat di tahun 2014 mencapai 19,03 Triliun Rupiah. Pada tahun 2015 Nilai PDRB mencapai 19,22 Triliun Rupiah dan pada tahun 2016 menurun menjadi 17,40 Triliun Rupiah. Untuk tahun 2017 Nilai PDRB kembali meningkat dari tahun sebelumnya mencapai 18,34 Triliun Rupiah dan terus meningkat di tahun 2018 mencapai 20,39 Triliun Rupiah. Sementara pada tahun 2019 Nilai PDRB Kabupaten Luwu Timur mencapai 20,99 Triliun Rupiah dan terus meningkat pada tahun 2020 mencapai Rp. 21,53 Triliun 
Rupiah. Selama 11 tahun terakhir (2010-2020) struktur perekonomian Kabupaten Luwu Timur di dominasi oleh 5 (lima) kategori lapangan usaha, diantaranya : Pertambangan dan Penggalian; Pertanian, Kehutanan, dan Perikanan; Konstruksi; Perdagangan Besar dan Eceran, Reparasi Mobil, dan Sepeda Motor; dan Industri Pengolahan. Hal ini dapat dilihat dari peranan masing-masing lapangan usaha terhadap pembentukan PDRB Kabupaten Luwu Timur.

\section{b) Hasil Pengolahan Data}

\section{Uji Asumsi Klasik}

Uji ini dilakukan untuk mengetahui bahwa data yang diolah adalah sah (tidak terdapat penyimpangan) serta distribusi normal, maka data tersebut akan diuji melalui uji asumsi klasik, yang terdiri dari : (a) Uji Normalitas, uji Normalitas bertujuan untuk menguji apakah dalam suatu model regresi linear variabel terikat dan variabel bebas keduanya Berdistribusi Normal atau tidak. Model regresi yang baik adalah data yang Berdistribusi Normal. Dalam penelitian ini, selain menggunakan Uji Normalitas dengan Grafik Histogram dan Probability Plot juga dilakukan uji alternatif dengan pengujian Kolmogorov Smirnov. Dasar Pengambilan Keputusan Uji Normalitas dengan Grafik Histogram dan Probability Plot adalah: Data dikatakan berdistribusi normal, jika data menyebar disekitar garis diagonal dan mengikuti arah garis diagonal atau grafik histogramnya.Sebaliknya data dikatakan tidak berdistribusi normal, jika data menyebar jauh dari arah garis atau tidak mengikuti diagonal atau grafik histogramnya. Adapun hasil output SPSS 26 untuk Grafik Histogram dan Probability Plot pada Uji Normalitas terlihat di bawah ini :

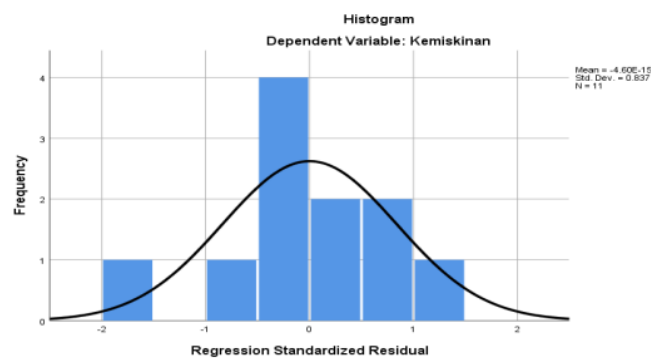

Gambar 3. Grafik Histogram

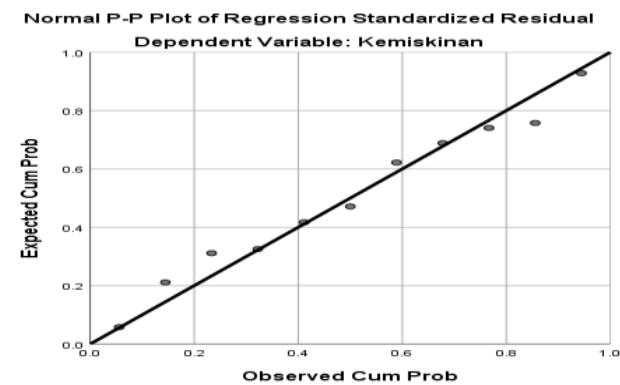

Gambar 4. Grafik Probability Plot

Dari hasil output SPSS 26 untuk Uji Normalitas terlihat pada grafik histogram dan Probability Plot, dimana data Ploting (titik-titik) yang menggambarkan data sesungguhnya Mengikuti Garis Diagonal, sehingga disimpulkan model regresi Berdistribusi Normal. Adapun Dasar Pengambilan Keputusan Uji Normalitas Kolmogorov Smirnov sebagai alternatif Uji Normalitas adalah : Jika Nilai Signifikansi > 0,05, maka Nilai Residual Berdistribusi Normal. Jika Nilai Signifikansi < 0,05, maka Nilai Residual Tidak Berdistribusi Normal 
Tabel 6. Uji One-Sample Kolmogorov-Smirnov Test

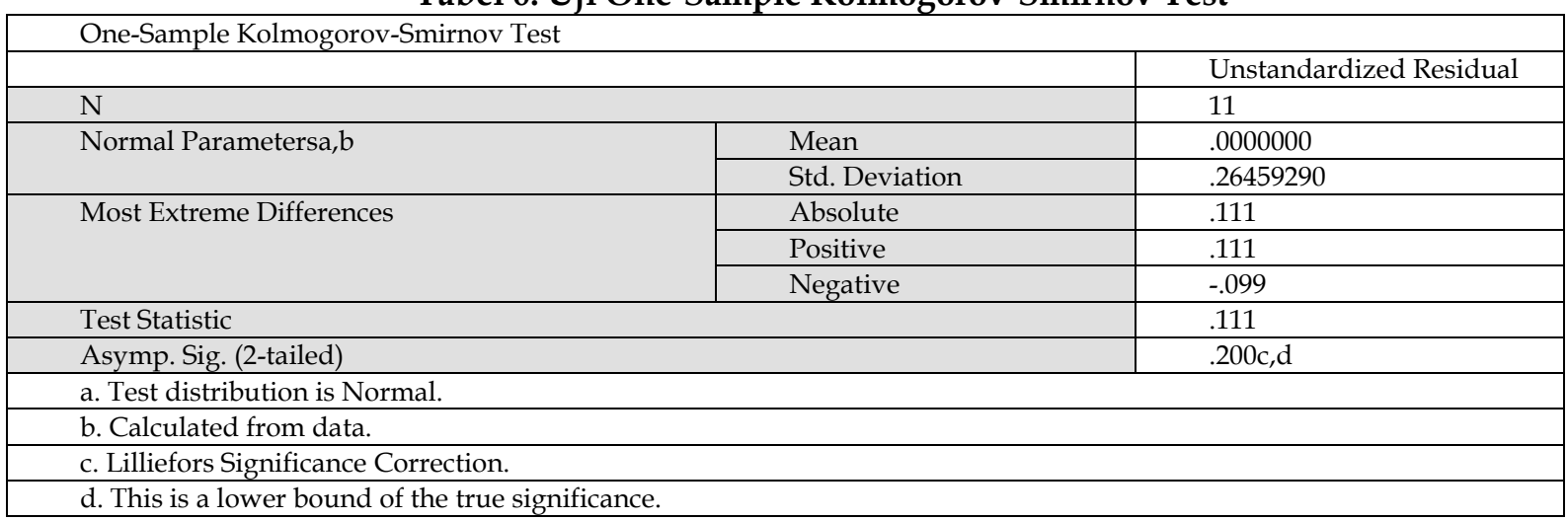

Sumber : Output SPSS 26, Data diolah Tahun 2021.

Kesimpulan Hasil Uji Normalitas Kolmogorov Smirnov, berdasarkan Hasil Uji Normalitas diketahui Nilai Signifikansi 0,200>0,05, maka dapat disimpulkan bahwa Nilai Residual Berdistribusi Normal. Uji Multikolineritas, bertujuan untuk mengetahui apakah terjadi interkorelasi (Hubungan yang kuat) anatar variabel independen. Model regresi yang baik ditandai dengan tidak terjadi interkorelasi antar variabel independen (tidak terjadi gejala Multikolineritas). Salah satu cara yang akurat untuk mendeteksi ada atau tidaknya gejala Multikolineritas adalah dengan menggunakan metode Tolerance dan VIF (Variance Inflation Factor). Dasar pengambilan keputusan Uji Multikolineritas Adalah melihat Nilai Tolerance : Jika Nilai Tolerance lebih besar dari $>0,10$ Maka artinya Tidak Terjadi Multikolineritas; Melihat Nilai VIF : Jika Nilai VIF lebih kecil dari < 10,00 Maka artinya Tidak Terjadi Multikolineritas.

Tabel 7. Uji Multikolineritas

\begin{tabular}{|c|c|c|c|c|c|c|c|}
\hline \multicolumn{8}{|l|}{ Coefficientsa } \\
\hline \multirow[b]{2}{*}{ Model } & \multicolumn{2}{|c|}{$\begin{array}{l}\text { Unstandardized } \\
\text { Coefficients }\end{array}$} & \multirow{2}{*}{$\begin{array}{c}\begin{array}{c}\text { Standardized } \\
\text { Coefficients }\end{array} \\
\text { Beta }\end{array}$} & \multirow[b]{2}{*}{$\mathrm{t}$} & \multirow[b]{2}{*}{ Sig. } & \multicolumn{2}{|c|}{ Collinearity Statistics } \\
\hline & $\mathrm{B}$ & Std. Error & & & & Tolerance & VIF \\
\hline (Constant) & 13.218 & 9.519 & & 1.389 & .208 & & \\
\hline Pengangguran & .029 & .054 & .135 & .546 & .602 & .342 & 2.926 \\
\hline IPM & -039 & .145 & -.092 & -.272 & .794 & .184 & 5.424 \\
\hline PDRB & -.165 & .074 & -.731 & -2.237 & .060 & .197 & 5.088 \\
\hline
\end{tabular}

a. Dependent Variable: Kemiskinan

Sumber : Output SPSS 26, Data diolah Tahun 2021.

Kesimpulan Uji Multikolineritas :

Nilai Tolerance Pengangguran adalah 0,342 > 0,10 Maka artinya Tidak Terjadi Multikolineritas;

Nilai Tolerance IPM adalah 0,184 > 0,10 Maka artinya Tidak Terjadi Multikolineritas;

Nilai Tolerance PDRB adalah 0,197 > 0,10 Maka artinya Tidak Terjadi Multikolineritas;

Nilai VIF Pengangguran adalah 2,926 < 10,00 Maka artinya Tidak Terjadi Multikolineritas;

Nilai VIF IPM adalah 5,424 < 10,00 Maka artinya Tidak Terjadi Multikolineritas;

Nilai VIF PDRB adalah 5,088 < 10,00 Maka artinya Tidak Terjadi Multikolineritas.

\section{Uji Heteroskedastisitas}

Uji Heteroskedastisitas bertujuan untuk mengetahui ada tidaknya kesamaan varian dari nilai residual untuk semua pengamatan pada model regresi. Heteroskedastisitas merupakan salah satu faktor yang menyebabkan model regresi linear tidak efisien dan akurat, sehingga model regresi linear yang baik ditandai dengan Tidak Terjadi Gejala Heteroskedastisitas. Ciri-ciri tidak terjadi Gejala Heteroskedastisitas : Titik-titik data menyebar diatas dan dibawah atau disekitar angka 0; Titik-titik tidak mengumpul hanya diatas atau dibawah saja; Penyebaran titik-titik tidak boleh membentuk pola bergelombang melebar kemudian menyempit dan melebar kembali. 


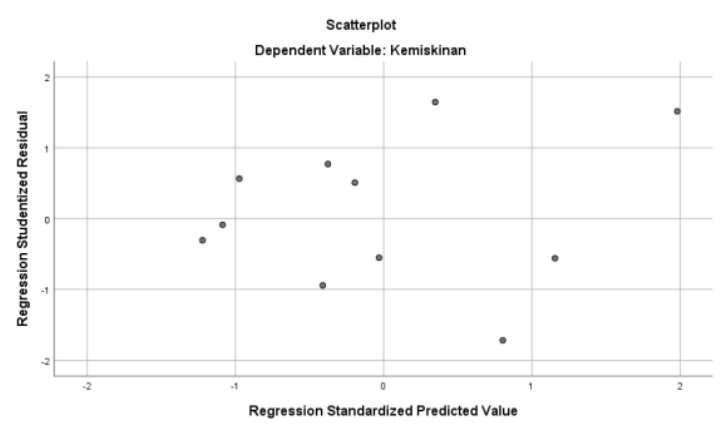

Gambar 5. Grafik Scatterplot

Sumber : Output SPSS 26, Data diolah Tahun 2021.

Berdasarkan output Scatterplot diatas terlihat bahwa titik-titik menyebar dan tidak membentuk pola yang jelas. Sehingga dapat disimpulkan bahwa Tidak Terjadi Masalah Heteroskedastisitas. Uji Heteroskedastisitas dengan melihat Grafik Scatterplot mempunyai kelemahan yang cukup signifikan sebab jumlah pengamatantertentu sangat mempengaruhi hasil ploting. Salah satu uji alternatif yang paling akurat untuk mendeteksi Heteroskedastisitas adalah dengan menggunakan Uji Glejser, yang dilakukan dengan cara meregresikan Variabel Independen dengan nilai absolut residualnya. Dasar pengambilan keputusan Uji Glejser adalah Jika Nilai Signifikansi (Sig) antara variabel independen dengan absolut residual lebih besar dari 0,05, maka tidak terjadi masalah Heteroskedastisitas.

Tabel 8. Hasil Analisis Uji Heteroskedastisitas

\begin{tabular}{|c|c|c|c|c|c|c|}
\hline \multicolumn{7}{|c|}{ Coefficientsa } \\
\hline & \multirow[b]{2}{*}{ Model } & \multicolumn{2}{|c|}{ Unstandardized Coefficients } & \multirow{2}{*}{$\begin{array}{l}\text { Standardized } \\
\text { Coefficients } \\
\text { Beta } \\
\end{array}$} & \multirow[b]{2}{*}{$t$} & \multirow[b]{2}{*}{ Sig. } \\
\hline & & $\mathrm{B}$ & Std. Error & & & \\
\hline \multirow[t]{4}{*}{1} & (Constant) & 27.763 & 18.829 & & 1.475 & .184 \\
\hline & Ln_Pengangguran & -.084 & .139 & -.303 & -.605 & .564 \\
\hline & Ln_IPM & -6.557 & 4.619 & -.985 & -1.419 & .199 \\
\hline & Ln_PDRB & .174 & .495 & .215 & .352 & .735 \\
\hline
\end{tabular}

Sumber : Output SPSS 26, Data diolah Tahun 2021.

Kesimpulan Uji Heteroskedastisitas dengan Uji Glejser : Nilai Signifikansi (Sig) Pengangguran adalah 0,564 > 0,05 Maka artinya Tidak Terjadi Masalah Heteroskedastisitas; Nilai Signifikansi (Sig) IPM adalah 0,199 > 0,05 Maka artinya Tidak Terjadi Masalah Heteroskedastisitas; Nilai Signifikansi (Sig) PDRB adalah 0,735 > 0,05 Maka artinya Tidak Terjadi Masalah Heteroskedastisitas.

\section{Uji Autokorelasi}

Uji Autokorelasi bertujuan untuk menguji apakah model regresi linear terdapat korelasi antara kesalahan pengganggu pada periode $t$ dengan kesalahan pada periode $t 1$ (sebelumnya). Dasar pengambilan keputusan Uji Autokorelasi :

$\mathrm{d}<\mathrm{dl}$ atau $\mathrm{d}>4$-dl, maka Terdapat Autokorelasi

$\mathrm{du}<\mathrm{d}<4$-du, maka Tidak Terdapat Autokorelasi

$\mathrm{dl}<\mathrm{d}<\mathrm{du}$ atau 4-du $<\mathrm{d}<4$-dl, maka Tidak Ada Kesimpulan

Tabel 9. Uji Autokorelasi

\begin{tabular}{|l|c|c|c|c|c|}
\hline \multicolumn{5}{|c|}{ Model Summaryb } \\
\hline Model & $\mathrm{R}$ & R Square & Adjusted R Square & $\begin{array}{c}\text { Std. Estimate } \\
\text { Estor of the }\end{array}$ & Durbin-Watson \\
\hline 1 & $.924 \mathrm{a}$ & .853 & .790 & .31625 & 2.303 \\
\hline a. Predictors: (Constant), PDRB, Pengangguran, IPM \\
\hline
\end{tabular}

Karena $=\mathrm{dl}<\mathrm{d}<\mathrm{du}=0.5948<2.303<1.9280$, maka Tidak Ada Kesimpulan 
Untuk memberikan kesimpulan yang lebih pasti jika terjadi masalah pada Durbin Watson Test yaitu nilai d terletak antara (4-du) dan (4-dl), maka digunakan alternatif UJI RUN TEST. Dasar pengambilan keputusan Uji Autokorelasi :

Jika Nilai Asymp. Sig (2 Tailed) lebih kecil < dari 0,05, maka Terdapat Gejala Autokorelasi

Jika Nilai Asymp. Sig (2 Tailed) lebih besar > dari 0,05, maka Tidak Terdapat Gejala Autokorelasi

Tabel 10. Uji Run Test

\begin{tabular}{|l|l|}
\hline \multicolumn{2}{|c|}{ Runs Test } \\
\hline Test Valuea & Unstandardized Residual \\
\hline Cases < Test Value & -.02279 \\
\hline Cases >= Test Value & 5 \\
\hline Total Cases & 6 \\
\hline Number of Runs & 11 \\
\hline Z & 6 \\
\hline Asymp. Sig. (2-tailed) & .000 \\
\hline a. Median & 1.000 \\
\hline
\end{tabular}

Sumber : Output SPSS 26, Data diolah Tahun 2021.

Diketahui Nilai Asymp. Sig (2 Tailed) sebesar 1,000 > dari 0,05, maka dapat disimpulkan bahwa Tidak Terdapat Gejala Autokorelasi, sehingga Analisis Regresi Linear dapat dilanjutkan.

\section{Uji Hipotesis}

Dalam penelitian ini dianalisis dengan menggunakan model regresi berganda. Analisis yang digunakan adalah regresi berganda karena variabelnya lebih dari satu atau dua. Analisis regresi linear berganda digunakan untuk mengetahui besarnya hubungan pengaruh variabel bebas (X1, X2 dan X3) terhadap variabel terikat (Y). Untuk memperoleh hasil yang lebih terarah, maka Peneliti menggunakan bantuan Perangkat Lunak Software SPSS 26. Tahapan pengujian hipotesis menggunakan regresi linear berganda ditempuh dengan langkah menentukan persamaan regresinya adalah :

Dimana :

$$
Y=b 0+b 1 X 1+b 2 X 2+b 3 X 3+e
$$

$\mathrm{Y}=$ Kemiskinan

bo $=$ Konstanta

$\mathrm{b} 1=$ Koefisien $\mathrm{X} 1$

b2 $=$ Koefisien $X 2$

b3 $=$ Koefisien X3

$\mathrm{X} 1=$ Variabel Pengangguran

$\mathrm{X} 2=$ Variabel Indeks Pembangunan Manusia

$\mathrm{X} 3=$ Variabel PDRB

$\mathrm{e}=$ Error term

Uji Signifikan merupakan prosedur yang digunakan untuk menguji kebenaran atau kesalahan dari hasil hipotesis nol dari sampel, ide dasar yang melatar belakangi pengujian signifikansi adalah uji statistic (estimator) dari distribusi sampel dari suatu statistik di bawah hipotesis nol. Keputusan untuk mengolah $\mathrm{HO}$ dibuat berdasarkan nilai uji statistik yang diperoleh dari data yang ada. Uji statistik terdiri dari pengujian Koefisien Determinasi (R2), pengujian Simultan (Uji f), dan pengujian Uji Parsial (Uji t).

\section{Uji Koefisien Determinasi (R2)}

Koefisien determinasi bertujuan untuk mengukur seberapa jauh Tingkat Kemiskinan dapat menjelaskan variasi variabel dependen. Pada pengujian hipotesis pertama koefisien determinasi dilihat dari besarnya nilai (Adjusted R2) untuk mengetahui seberapa jauh variabel bebas yaitu Pengangguran, IPM dan PDRB terhadap Tingkat Kemiskinan. Nilai (Adjusted R2) mempunyai interval antar 0 dan 1. Jika nilai Adjusted R2 bernilai besar (mendekati 1) berarti variabel bebas dapat memberikan hampir semua informasi yang dibutuhkan untuk memprediksi variabel dependen. 
Sedangkan jika (Adjusted R2) bernilai kecil berarti kemampuan variabel bebas dalam menjelaskan variabel dependen sangat terbatas.Secara umum koefisien determinasi untuk data silang (crossection) relatif rendah karena adanya variasi yang besar antara masing-masing pengamatan, sedangkan untuk data runtun biasanya mempunyai nilai koefisiean determinasi yang tinggi.

Tabel 11. Koefisien Determinasi $\left(\mathbf{R}^{2}\right)$

\begin{tabular}{|c|c|c|c|c|c|}
\hline \multicolumn{6}{|c|}{ Model Summaryb } \\
\hline Model & $\mathrm{R}$ & R Square & Adjusted R Square & $\begin{array}{c}\text { Std. Error of the } \\
\text { Estimate }\end{array}$ & Durbin-Watson \\
\hline 1 & $.924 \mathrm{a}$ & .853 & .790 & .31625 & 2.303 \\
\hline \multicolumn{2}{|l|}{ a. Predictors: (Constant), PDRB, Pengangguran, IPM } \\
\hline \multicolumn{2}{|l}{ b. Dependent Variable: Kemiskinan } \\
\hline
\end{tabular}

Sumber: Output SPSS 26, Data diolah Tahun 2021.

Berdasarkan Hasil Analisis Regresi Berganda Nilai R Square adalah 0,853, sehingga dapat disimpulkan secara Simultan Pengaruh Variabel Independen $(X)$ terhadap Variabel Dependen $(Y)$ adalah sebesar $85,3 \%$

\section{Kofisien Determinan (Parsial/Sumbangan Preditor)}

Tabel 12. Koefisien Regresi (Beta)

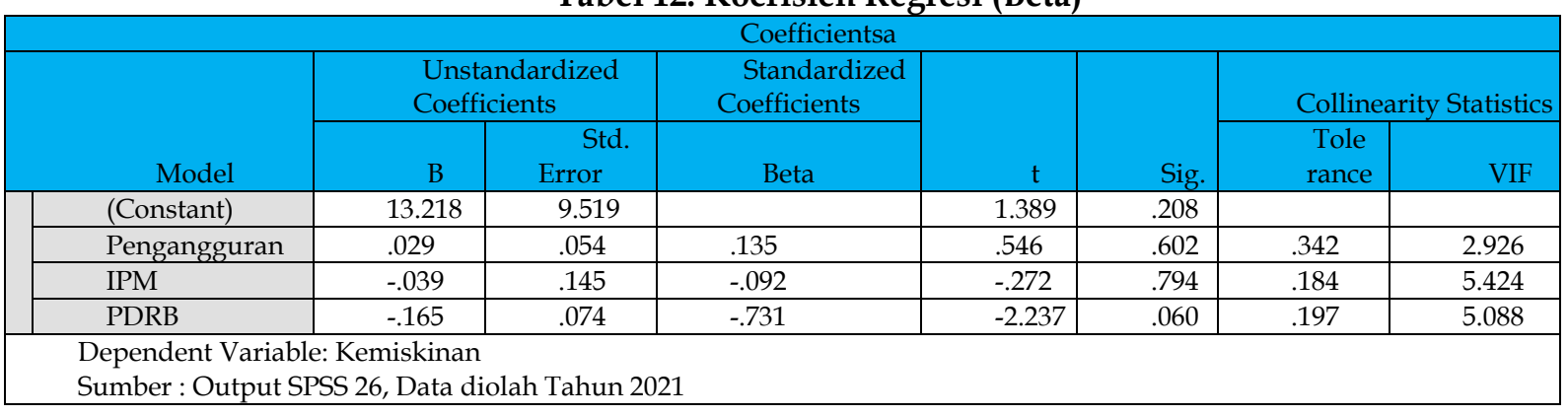

Tabel 13. Koefisien Korelasi

\begin{tabular}{|c|c|c|c|c|c|}
\hline \multicolumn{6}{|c|}{ Correlations } \\
\hline & & Kemiskinan & Pengangguran & IPM & PDRB \\
\hline \multirow{4}{*}{$\begin{array}{l}\text { Pearson } \\
\text { Correlation }\end{array}$} & Kemiskinan & 1.000 & .778 & -.848 & -.917 \\
\hline & Pengangguran & .778 & 1.000 & -.795 & -.780 \\
\hline & IPM & -.848 & -.795 & 1.000 & .888 \\
\hline & PDRB & -.917 & -.780 & .888 & 1.000 \\
\hline \multirow{4}{*}{$\begin{array}{l}\text { Sig. (1- } \\
\text { tailed) }\end{array}$} & Kemiskinan & . & .002 & .000 & .000 \\
\hline & Pengangguran & .002 & . & .002 & .002 \\
\hline & IPM & .000 & .002 & . & .000 \\
\hline & PDRB & .000 & .002 & .000 & . \\
\hline \multirow[t]{4}{*}{$\mathrm{N}$} & Kemiskinan & 11 & 11 & 11 & 11 \\
\hline & Pengangguran & 11 & 11 & 11 & 11 \\
\hline & IPM & 11 & 11 & 11 & 11 \\
\hline & PDRB & 11 & 11 & 11 & 11 \\
\hline
\end{tabular}

Sumber : Output SPSS 26, Data diolah Tahun 2021.

Sumbangan Prediktor : Merupakan penjabaran dari besarnya kontribusi pengaruh (dalam hitungan persen \%) yang diberikan oleh masing-masing variabel Independen $(X)$ terhadap Variabel Dependen (Y)

Tabel 14. Sumbangan Prediktor

\begin{tabular}{|c|c|c|c|}
\hline Variabel & Koefisien Regresi (Beta) & Koefisien Korelasi & 0,778 \\
\hline X1 & 0,135 & $-0,848$ \\
\hline X2 & $-0,092$ & $-0,917$ \\
\hline X3 & $-0,731$ & 85,3 \\
\hline
\end{tabular}

Sumbangan Efektif (SE) : adalah ukuran sumbangan suatu variabel independen terhadap variabel dependen dalam analisis regresi. Penjumlahan dari SE semua variabel independen adalah sama dengan jumlah nilai R Square (R2). 
Tabel 15. Sumbangan Efektif

\begin{tabular}{|c|c|}
\hline SE & NILAI \\
\hline X1 & 10,5 \\
\hline X2 & 7,8 \\
\hline X3 & 67,0 \\
\hline R SQUARE & 85.3 \\
\hline
\end{tabular}

Berdasarkan hasil perhitungan diatas, dapat diketahui bahwa : Sumbangan Efektif (SE) Variabel Pengangguran (X1) terhadap Tingkat Kemiskinan (Y) adalah sebesar 10,5\%. Sumbangan Efektif (SE) Variabel IPM (X2) terhadap Tingkat Kemiskinan (Y) adalah sebesar 7,8\%. Sumbangan Efektif (SE) Variabel PDRB (X3) terhadap Tingkat Kemiskinan (Y) adalah sebesar 67,0\%. Sumbangan Relatif (SR) : adalah ukuran sumbangan suatu variabel independen terhadap jumlah kuadrat regresi. Jumlah SR dari semua variabel independen adalah $100 \%$ atau sama dengan 1 .

Tabel 16. Sumbangan Relatif

\begin{tabular}{|c|c|}
\hline SR & NILAI \\
\hline X1 & 12,3 \\
\hline X2 & 9,1 \\
\hline X3 & 78,6 \\
\hline R SQUARE & 100.0 \\
\hline
\end{tabular}

Berdasarkan hasil perhitungan diatas, dapat diketahui bahwa : Sumbangan Relatif (SR) Variabel Pengangguran (X1) terhadap Tingkat Kemiskinan (Y) adalah sebesar 12,3\% Sumbangan Relatif (SR) Variabel IPM (X2) terhadap Tingkat Kemiskinan (Y) adalah sebesar 9,1\% Sumbangan Relatif (SR) Variabel PDRB (X3) terhadap Tingkat Kemiskinan (Y) adalah sebesar 78,6\%

\section{Uji Simultan (Uji f)}

Uji f-statistik ini adalah pengujian yang bertujuan untuk mengetahui seberapa besar pengaruh koefisien regresi secara bersama-sama terhadap variabel dependen. Untuk mengetahui signifikan tidaknya, maka derajat signifikan yang digunakan sebesar $5 \%$ atau $(\alpha=0,05)$. Apabila nilai $\mathrm{F}$ hasil perhitungan lebih besar dari pada nilai $\mathrm{F}$ menurut tabel maka hipotesis alternatif variabel independen berpengaruh signifikan terhadap variabel dependen. Kriteria pengambil keputusan :

Ho : $\beta=0$ artinya, tidak ada pengaruh antara variabel bebas secara simultan terhadap variabel terikat.

Ha : $\beta>$ artinya, ada pengaruh antara variabel bebas secara simultan terhadap variabel terikat.

$\mathrm{F}=\mathrm{R} 2(\mathrm{n}-(\mathrm{k}-1)$

$(1-R)(K)$

Keterangan :

$\mathrm{R}=$ Koefisisen korelasi berganda

$\mathrm{K}=$ Jumlah variabel bebas

$\mathrm{n}=$ Jumlah sampel

Dengan tingkat signifikan (a) yang digunakan adalah 5\% distribusi $\mathrm{F}$ dengan derajat kebebasan $(\alpha ; \mathrm{K}-1, \mathrm{n}-\mathrm{k})$. Kriteria Pengujian : F hitung $<\mathrm{F}$ tabel $=$ diterima, artinya variabel independen secara serentak atau bersamaan tidak mempengaruhi variabel dependen secara signifikan. $\mathrm{F}$ hitung $>\mathrm{F}$ tabel = Ho ditolak, artinya variabel independen secara serentak atau bersama-sama mempengaruhi variabel dependen secara signifikan.

Tabel 17. Hasil Uji Simultan (Uji f)

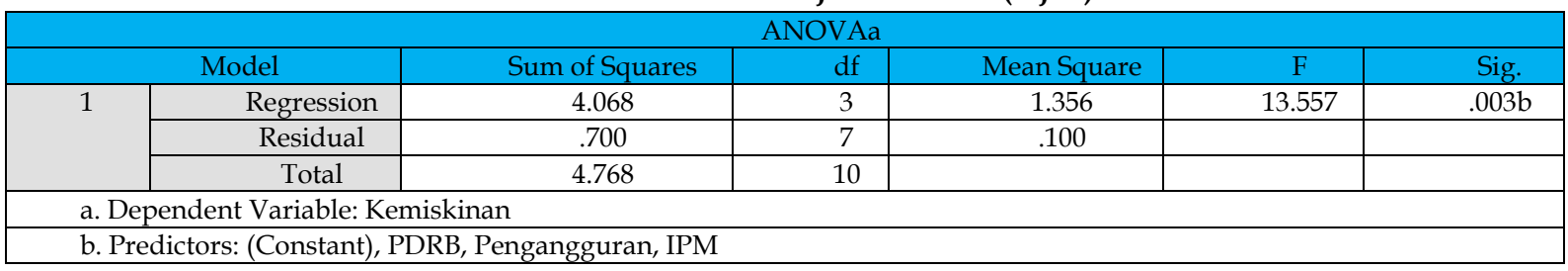

Sumber : Output SPSS 26, Data diolah Tahun 2021. 
Dasar Pengambilan Keputusan Uji f Simultan (Regresi Linear Berganda) berdasarkan Nilai Signifikansi menurut Imam Ghozali (2011 : 101) jika Nilai Sig. < 0,05, maka artinya Variabel Independen $(X)$ secara Simultan Berpengaruh terhadap Variabel Dependen (Y). Kesimpulan Hasil Uji f Simultan : Nilai Sig. Pengangguran (X1), IPM (X2) dan PDRB (X3) adalah 0,003 < 0,05, sehingga dapat disimpulkan Pengangguran (X1), IPM (X2) dan PDRB (X3), Secara Simultan Berpengaruh Signifikan terhadap Kemiskinan (Y). Dasar Pengambilan Keputusan Uji f Simultan (Regresi Linear Berganda) berdasarkan Nilai Hitung dan Tabel : Menurut V. Wiratna Sujarweni (2014:154) jika Nilai F Hitung > F Tabel, maka artinya Variabel Independen (X) Secara Simultan Berpengaruh terhadap Variabel Dependen (Y). Rumus mencari F Tabel $=(\mathrm{k} ; \mathrm{n}-\mathrm{k})=(3 ; 11-3)=(3 ; 8)=4,07$

Kesimpulan Hasil Uji f Simultan : Nilai f hitung Pengangguran (X1), IPM (X2) dan PDRB (X3) adalah 13,557 > 4,07, sehingga dapat disimpulkan Pengangguran (X1), IPM (X2) dan PDRB (X3), Secara Simultan Berpengaruh Signifikan terhadap Kemiskinan $(Y)$.

\section{Uji Parsial (Uji t)}

Uji ini digunakan untuk mengetahui apakah masing-masing variabel independen secara sendirisendiri mempunyai pengaruh secara signifikan terhadap variabel dependen. Dengan kata lain, untuk mengetahui apakah masing-masing variabel independen dapat menjelaskan perubahan yang terjadi pada variabel dependen secara nyata. Dimana $\beta 1$ Koefisien variabel independen ke-1 yaitu nilai parameter hipotesis. Biasanya nilai $\beta$ dianggap nol, artinya tidak ada pengaruh variabel X1 terhadap Y.

Tabel 18. Hasil Uji Parsial (Uji t)

\begin{tabular}{|c|c|c|c|c|c|c|c|c|}
\hline \multicolumn{9}{|c|}{ Coefficientsa } \\
\hline \multirow{2}{*}{\multicolumn{2}{|c|}{ Model }} & \multicolumn{2}{|c|}{$\begin{array}{l}\text { Unstandardized } \\
\text { Coefficients }\end{array}$} & \multirow{2}{*}{$\begin{array}{c}\begin{array}{c}\text { Standardized } \\
\text { Coefficients }\end{array} \\
\text { Beta }\end{array}$} & \multirow[b]{2}{*}{$t$} & \multirow[b]{2}{*}{ Sig. } & \multicolumn{2}{|c|}{ Collinearity Statistics } \\
\hline & & B & Std. Error & & & & Tolerance & VIF \\
\hline 1 & (Constant) & 13.218 & 9.519 & & 1.389 & .208 & & \\
\hline & Pengangguran & .029 & .054 & .135 & .546 & .602 & .342 & 2.926 \\
\hline & IPM & -.039 & .145 & -.092 & -.272 & .794 & .184 & 5.424 \\
\hline & PDRB & -.165 & .074 & -.731 & $2.237^{-}$ & .060 & .197 & 5.088 \\
\hline
\end{tabular}

Dasar Pengambilan Keputusan Uji t Parsial (Regresi Linear Berganda) berdasarkan Nilai Signifikansi menurut Imam Ghozali (2011:101) jika Nilai Sig. < 0,05, maka artinya Variabel Independen $(X)$ secara Parsial Berpengaruh Signifikan terhadap Variabel Dependen $(Y)$ Kesimpulan Hasil Uji t Parsial : Nilai Sig. Pengangguran 0,602 > 0,05, sehingga dapat disimpulkan Pengangguran (X1) secara Parsial Tidak Berpengaruh Signifikan terhadap Tingkat Kemiskinan (Y); Nilai Sig. IPM 0,794 > 0,05, sehingga dapat disimpulkan IPM (X2) secara Parsial Tidak Berpengaruh Signifikan terhadap Tingkat Kemiskinan (Y); Nilai Sig. PDRB 0,060 > 0,05, sehingga dapat disimpulkan PDRB (X3) secara Parsial Tidak Berpengaruh Signifikan terhadap Tingkat Kemiskinan (Y). Dasar Pengambilan Keputusan Uji t Parsial (Regresi Linear Berganda) berdasarkan Nilai Hitung dan Tabel : Menurut V. Wiratna Sujarweni (2014:155) jika Nilai $t$ hitung $>t$ tabel, maka artinya Variabel Independen $(\mathrm{X})$ secara Parsial Berpengaruh terhadap Variabel Dependen $(\mathrm{Y})$ Rumus mencari $\mathrm{t}$ tabel $=$ $(\alpha / 2 ; \mathrm{n}-\mathrm{k}-1)=(0,05 / 2 ; 11-3-1)=(0,025 ; 7)=2,36462$ Kesimpulan Hasil Uji $\mathrm{t}$ Parsial $:$ Nilai $\mathrm{t}$ Hitung Pengangguran adalah 0,546 < $\mathrm{t}$ Tabel adalah 2.36462, sehingga dapat disimpulkan Variabel Pengangguran (X1) secara Parsial Berpengaruh Positif dan Tidak Signifikan terhadap Tingkat Kemiskinan (Y); Nilai $\mathrm{t}$ Hitung IPM adalah $-0,272<\mathrm{t}$ Tabel adalah 2.36462, sehingga dapat disimpulkan Variabel IPM (X2) secara Parsial Berpengaruh Negatif dan Tidak Signifikan terhadap Tingkat Kemiskinan (Y); Nilai t Hitung PDRB adalah -2.237 < t Tabel adalah 2.36462, sehingga dapat disimpulkan Variabel PDRB (X3) secara Parsial Berpengaruh Negatif dan Tidak Signifikan terhadap Tingkat Kemiskinan $(Y)$ 


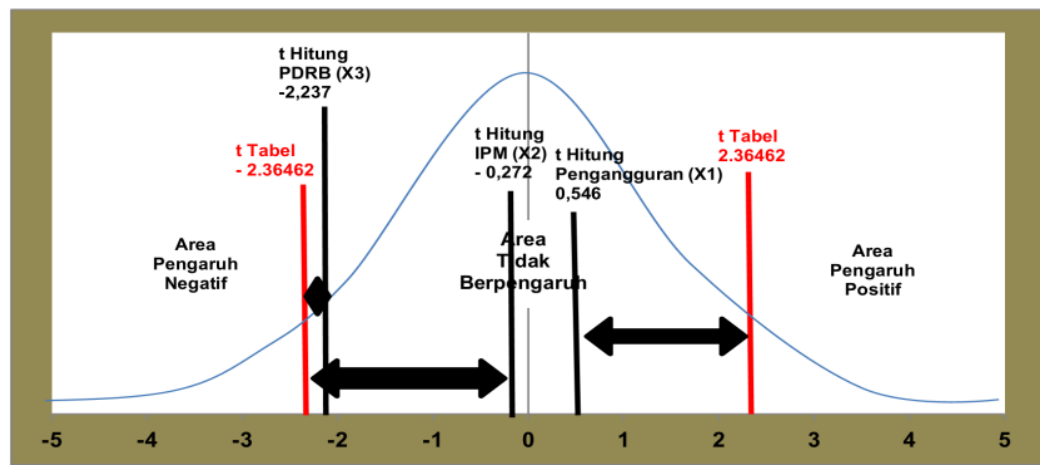

Gambar 7. Perbandingan Nilai t dengan Kurva

Kesimpulan Hasil Uji t Parsial : Pengangguran (X1) Berpengaruh Negatif dan Tidak Signifikan terhadap Kemiskinan (Y); IPM (X2) Berpengaruh Negatif dan Tidak Signifikan terhadap Kemiskinan (Y); Pengangguran (X3) Berpengaruh Negatif dan Tidak Signifikan terhadap Kemiskinan (Y).

Tabel 19. Rekapitulasi Hasil Analisis Regresi Berganda

\begin{tabular}{|c|c|c|c|c|c|c|c|}
\hline \multirow[b]{3}{*}{ Model } & \multicolumn{5}{|c|}{ Coefficientsa } & & \\
\hline & \multicolumn{2}{|c|}{$\begin{array}{l}\text { Unstandardized } \\
\text { Coefficients }\end{array}$} & \multirow{2}{*}{$\begin{array}{c}\begin{array}{c}\text { Standardized } \\
\text { Coefficients }\end{array} \\
\text { Beta }\end{array}$} & \multirow[b]{2}{*}{$\mathrm{t}$} & \multirow[b]{2}{*}{ Sig. } & \multicolumn{2}{|c|}{ Collinearity Statistics } \\
\hline & B & $\begin{array}{l}\text { Std. } \\
\text { Error }\end{array}$ & & & & Tolerance & VIF \\
\hline (Constant) & 13.218 & 9.519 & & 1.389 & .208 & & \\
\hline Pengangguran & .029 & .054 & .135 & .546 & .602 & .342 & 2.926 \\
\hline IPM & -.039 & .145 & -.092 & -.272 & .794 & .184 & 5.424 \\
\hline PDRB & -.165 & .074 & -.731 & -2.237 & .060 & .197 & 5.088 \\
\hline
\end{tabular}

Sumber : Output SPSS 26, Data diolah Tahun 2021.

Berdasarkan Tabel 19 diatas, diperoleh persamaan sebagai berikut :

$$
Y=13,218+0,029 \times 1-0,039 \times 2-0,165 \times 3
$$

Dari Persamaan Regresi diatas dapat diinterpretasikan sebagai berikut :

Nilai Koefisien $\beta 0$ sebesar 13,218. Artinya jika Variabel Pengangguran (X1), IPM (X2) dan PDRB (X3) konstan atau $X=0$, maka Tingkat Kemiskinan sebesar 13,218; Nilai Koefisien $\beta 1=0,029$. Artinya jika Variabel Pengangguran mengalami penurunan sebesar 1\%, maka mengakibatkan Kemiskinan di Kabupaten Luwu Timur mengalami penurunan 0,029 dengan asumsi IPM dan PDRB konstan. Koefisien bernilai positif artinya terjadi hubungan Positif antara Pengangguran dan Tingkat Kemiskinan, karena semakin menurunnya Jumlah Pengangguran maka Tingkat Kemiskinan juga menurun. Sehingga hipotesis yang diuji dalam penelitian ini yaitu : Pengangguran Berpengaruh Positif dan Tidak Signifikan terhadap Tingkat Kemiskinan di Kabupaten Luwu Timur" ditolak. Nilai Koefisien $\beta 2=-0,039$. Artinya jika Variabel Indeks Pembangunan Manusia mengalami kenaikan sebesar 1\%, maka mengakibatkan Kemiskinan di Kabupaten Luwu Timur mengalami penurunan 0,039 dengan asumsi Pengangguran dan PDRB konstan. Koefisien bernilai Negatif artinya terjadi hubungan negatif antara Indeks Pembangunan Manusia dan Tingkat Kemiskinan, karena semakin meningkatnya Indeks Pembangunan Manusia maka Tingkat Kemiskinan menurun. Sehingga hipotesis yang diuji dalam penelitian ini yaitu : "Indeks Pembangunan Manusia Berpengaruh Negatif dan Tidak Signifikan terhadap Tingkat Kemiskinan di Kabupaten Luwu Timur" ditolak. Nilai Koefisien $\beta 3=-0,165$. Artinya jika Variabel PDRB mengalami kenaikan sebesar $1 \%$, maka mengakibatkan Kemiskinan di Kabupaten Luwu Timur mengalami penurunan 0,165 dengan asumsi Pengangguran dan IPM konstan. Koefisien bernilai Negatif artinya terjadi hubungan negatif antara PDRB dan Tingkat Kemiskinan, karena semakin meningkatnya PDRB maka Tingkat Kemiskinan menurun. Sehingga hipotesis yang diuji dalam penelitian ini yaitu : "PDRB Berpengaruh Negatif dan Tidak Signifikan terhadap Tingkat Kemiskinan di Kabupaten Luwu Timur" ditolak. 
c) Pembahasan

1) Pengaruh Pengangguran Terhadap Tingkat Kemiskinan

Berdasarkan hasil pengujian statistik diketahui bahwa Pengangguran berpengaruh positif dan tidak signifikan terhadap Tingkat Kemiskinan. Hal itu dapat disimpulkan berdasarkan Tabel 22 yang menunjukkan nilai Signifikan Variabel Pengangguran yaitu 0,602 >0,05, sehingga dapat dikatakan Variabel Pengangguran Tidak Berpengaruh Signifikan terhadap Tingkat Kemiskinan di Kabupaten Luwu Timur. Menurut Yacob (2012) bahwa upaya menurunkan tingkat pengangguran dan tingkat kemiskinan adalah sama pentingnya. Secara teori, jika masyarakat tidak menganggur berarti mempunyai pekerjaan dan penghasilan, dan dengan penghasilan tersebut diharapkan dapat memenuhi kebutuhan hidup. Jika kebutuhan hidup terpenuhi, maka tidak akan ada yang miskin. Sehingga dikatakan dengan tingkat pengangguran rendah maka Tingkat Kemiskinan juga rendah. Hal tersebut sejalan dengan Hasil Penelitian yang dilakukan oleh Ita Aristina, Made Kembar Sri Budhi, I G.A.P. Wirathi, Ida Bagus Darsana yang berjudul "Pengaruh Tingkat Pendidikan, Pengangguran dan Pertumbuhan Ekonomi Terhadap Kemiskinan di Provinsi Bali" yang menyimpulkan variabel Pengangguran berpengaruh positif dan signifikan terhadap Kemiskinan di Provinsi Bali. Sementara Penelitian yang dilakukan oleh Shidiq Ramdan Dinata yang berjudul "Pengaruh Indeks Pembangunan Manusia, Pertumbuhan Ekonomi, Jumlah Penduduk Dan Tingkat Pengangguran Terhadap Kemiskinan Di Provinsi Riau Tahun 2003-2018" menyimpulkan Tingkat Pengangguran tidak berpengaruh signifikan terhadap kemiskinan. Penelitian tersebut sejalan dengan dengan hasil penelitian ini yang menyatakan bahwa Pengangguran Berpengaruh Positif dan Tidak Signifikan terhadap Tingkat Kemiskinan di Kabupaten Luwu Timur pada periode Tahun 2010-2020.

Pengangguran tidak berpengaruh signifikan terhadap tingkat kemiskinan di Kabupaten Luwu Timur karena masih banyak individu yang aktif mencari pekerjaan sementara lapangan pekerjaan terbatas, ditambah lagi kebanyakan pengangguran yang terjadi di Kabupaten Luwu Timur tergolong ke dalam pengangguran Friksional. Pengangguran dalam kategori ini adalah kekuatan pendatang kerja baru yang mencari pekerjaan pertamanya dan pekerja-pekerja yang bersifat sementara, karena munculnya pekerja-pekerja tersebut berpindah ke lokasi atau pekerjaan baru dimana pekerja akan merasa lebih produktif. Besarnya pengangguran pada kategori tersebut tersebut didorong karena melihat kondisi Kabupaten Luwu Timur yang kaya akan sumber daya alam diantaranya sektor pertambangan dan sektor pertanian. Keberadaan perusahaan besar seperti PT. Vale Indonesia, Tbk rupanya belum mampu mengurangi jumlah pengangguran di Kabupaten Luwu Timur karena penerimaan tenaga kerja yang terbatas. Sementara untuk wilayah diluar tambang seperti pada sektor pertanian, sebagian besar tidak lagi membutuhkan tenaga kerja harian karena petani telah ditunjang dengan alat mesin pertanian.

2) Pengaruh Indeks Pembangunan Manusia Terhadap Tingkat Kemiskinan

Berdasarkan hasil pengujian statistik diketahui bahwa Indeks Pembangunan Manusia berpengaruh negatif dan tidak signifikan terhadap Tingkat Kemiskinan. Hal itu dapat disimpulkan berdasarkan Tabel 22 yang menunjukkan nilai Signifikan Variabel Indeks Pembangunan Manusia yaitu 0,794 > 0,05, sehingga dapat dikatakan Variabel Indeks Pembangunan Manusia Tidak Berpengaruh Signifikan terhadap Tingkat Kemiskinan di Kabupaten Luwu Timur. Amartya Sen (1989) mendefinisikan pembangunan manusia sebagai perluasan kebebasan nyata yang dinikmati oleh manusia. Kebebasan bergantung pada faktor sosial ekonomi seperti akses pendidikan, kesehatan, ketenagakerjaan, dan politik. Mahbub ul Haq (1995) berpendapat bahwa pembangunan manusia merupakan proses perluasan pilihan yaitu kebebasan berpolitik, partisipasi dalam kehidupan bermasyarakat, pilihan untuk berpendidikan, bertahan hidup dan sehat, serta menikmati standar hidup layak. Kedua ahli tersebut merupakan cikal bakal lahirnya konsep pembangunan manusia yang digunakan oleh United Nations Development Programme (UNDP).

Dengan masyarakat yang sehat dan berpendidikan yang baik, peningkatan produktifitas masyarakat akan meningkatkan pula pengeluaran untuk konsumsinya, ketika pengeluaran untuk konsumsi meningkat, maka Tingkat Kemiskinan akan menurun. Di sisi lain, rendahnya Indeks Pembangunan Manusia (IPM) berakibat pada rendahnya produktivitas kerja dari penduduk. Rendahnya produktivitas berakibat pada rendahnya perolehan pendapatan. Sehingga dengan rendahnya pendapatan menyebabkan tingginya Tingkat Kemiskinan. Hal tersebut sejalan dengan Hasil Penelitian yang dilakukan oleh Ridho Andykha Putera (2018) yang berjudul “Analisis Pengaruh 
PDRB, Tingkat Pengangguran, dan IPM Terhadap Tingkat Kemiskinan di Provinsi Jawa Tengah" yang menyimpulkan variabel IPM berpengaruh negatif dan signifikan terhadap Tingkat Kemiskinan.

Sementara Penelitian yang dilakukan oleh Lily Leonita, Rini Kurnia Sari yang berjudul "Pengaruh PDRB, Pengangguran dan Pembangunan Manusia Terhadap Kemiskinan Di Indonesia" menyimpulkan IPM tidak berpengaruh terhadap kemiskinan. Penelitian tersebut sejalan dengan dengan hasil penelitian ini yang menyatakan bahwa Indeks Pembangunan Manusia Berpengaruh Negatif dan Tidak Signifikan terhadap Tingkat Kemiskinan di Kabupaten Luwu Timur pada periode Tahun 2010-2020. IPM yang terdiri dari komponen pendidikan, kesehatan dan standar hidup yang layak sangat menentukan kualitas manusia karena dengan Indeks Pembangunan Manusia menggambarkan sejauh mana hasil dari pembangunan manusia dapat di akses oleh lapisan masyarakat. Tingginya Indeks Pembangunan Manusia tersebut belum berpengaruh signifikan terhadap Tingkat Kemiskinan karena dari tiga komponen pembentuknya yaitu komponen Pengeluaran Per Kapita yang tergolong cukup tinggi mencapai 12,814 juta per kapita/tahun pada tahun 2020 belum mewakili secara menyeluruh kondisi kesejahteraan penduduk di Kabupaten Luwu Timur.

\section{3) Pengaruh PDRB Terhadap Tingkat Kemiskinan}

Berdasarkan hasil pengujian statistik diketahui bahwa PDRB berpengaruh negatif dan tidak signifikan terhadap Tingkat Kemiskinan. Hal itu dapat disimpulkan berdasarkan Tabel 22 yang menunjukkan nilai Signifikan Variabel Pengangguran yaitu 0,060 >0,05, sehingga dapat dikatakan Variabel PDRB Tidak Berpengaruh Signifikan terhadap Tingkat Kemiskinan di Kabupaten Luwu Timur. Produk Domestik Regional Bruto (PDRB) menurut Badan Pusat Statistik (2020) didefinisikan sebagai jumlah nilai tambah yang dihasilkan oleh seluruh unit usaha dalam suatu wilayah, atau merupakan jumlah seluruh nilai barang dan jasa akhir yang dihasilkan oleh seluruh unit ekonomi di suatu wilayah. Pertumbuhan Produk Domestik Regional Bruto digunakan untuk memahami dinamika perekonomian suatu wilayah dengan melihat percepatan perekonomiannya. Hal ini menunjukkan bahwa dengan peningkatan pertumbuhan Produk Domestik Regional Bruto mengindikasikan adanya kenaikan permintaan akan barang dan jasa, artinya kebutuhan masyarakat akan barang dan jasa akan meningkat, sehingga secara tidak langsung dengan peningkatan pertumbuhan Produk Domestik Regional Bruto mampu mengurangi kemiskinan yang selalu diidentikkan dengan tidak mampunya masyarakat dalam pemenuhan kebutuhan. Dapat dikatakan bahwa ketika perekonomian suatu daerah mengalami peningkatan maka Tingkat Kemiskinan akan mengalami penurunan.

Hal tersebut sejalan dengan Hasil Penelitian yang dilakukan oleh Putri Sari M J Silaban, Permata Sari Br Sembiring, Vini Alvionita Br Sitepu, Jessica Putri Br.Sembiring (2021) yang berjudul "Pengaruh IPM dan PDRB terhadap Jumlah Penduduk Miskin di Sumatera Utara Tahun 2002-2017" yang menyimpulkan Secara parsial Produk Domestik Regional Bruto (PDRB) memiliki pengaruh negatif dan signifikan terhadap jumlah penduduk miskin di Sumatera Utara pada tahun 2002 sampai dengan 2017. Sementara Penelitian yang dilakukan oleh Fatkhul Mufid Cholili, M. Pudjihardjo yang berjudul "Analisis Pengaruh Pengangguran, Produk Domestik Regional Bruto (PDRB), Dan Indeks Pembangunan Manusia (IPM) Terhadap Jumlah Penduduk Miskin Studi Kasus 33 Provinsi di Indonesia" menyimpulkan secara parsial PDRB tidak berpengaruh signifikan terhadap tingkat kemiskinan. Penelitian tersebut sejalan dengan dengan hasil penelitian ini yang menyatakan bahwa PDRB Berpengaruh Negatif dan Tidak Signifikan terhadap Tingkat Kemiskinan di Kabupaten Luwu Timur pada periode Tahun 2010-2020.

PDRB Berpengaruh Negatif dan Tidak Signifikan terhadap Tingkat Kemiskinan disebabkan karena tidak tersebarnya hasil pendistribusian pembangunan dan perekonomian ke seluruh wilayah yang ada di Kabupaten Luwu Timur. Perkembangan PDRB hanya dapat dirasakan oleh sebagian wilayah yang ada Kabupaten Luwu Timur, sehingga perkembangan PDRB tersebut belum mampu berdampak kepada seluruh lapisan masyarakat. Berkaitan dengan upaya peningkatan kesejahteraan masyarakat, perkembangan PDRB yang tinggi juga harus diikuti dengan pemerataan pembangunan. Pembangunan yang hanya terfokus pada tingginya PDRB akan menimbulkan dua masalah krusial yakni kesenjangan ekonomi dan kemiskinan. Kesenjangan ekonomi yang dimaksud adalah adanya ketimpangan dalam distribusi pendapatan yang ditunjukkan dengan Gini Rasio di Kabupaten Luwu Timur yang cenderung mengalami kenaikan yang mencapai 0.405 poin di tahun 2020 . Berawal dari 
distribusi pendapatan yang tidak merata yang kemudian memicu terjadinya ketimpangan pendapatan sebagai dampak dari perubahan tingkat kesejahteraan yang berbeda antar kelompok masyarakat. Ketimpangan akan semakin parah jika tingkat kesejahteraan masyarakat kelompok berpendapatan bawah tumbuh dengan lambat atau bahkan turun, sedangkan tingkat kesejahteraan kelompok berpendapatan atas tumbuh dengan cepat. Hal ini akan menjadi sangat serius apabila kedua masalah tersebut berlarut-larut dan di biarkan semakin parah, yang pada akhirnya akan menimbulkan konsekuensi gejolak politik dan sosial yang dampaknya cukup negatif. Berdasarkan hasil Penelitian Pengaruh Pengangguran, Indeks Pembangunan Manusia, dan PDRB di Kabupaten Luwu Timur Tahun 2010-2020, maka diperoleh beberapa kesimpulan sebagai berikut :

1) Hasil penelitian menunjukkan bahwa Pengangguran berpengaruh positif tapi tidak signifikan terhadap Tingkat Kemiskinan. Hal ini mengindikasikan bahwa dengan menurunnya pengangguran, belum dapat menurunkan tingkat kemiskinan secara signifikan di Kabupaten Luwu Timur. Kondisi tersebut juga terlihat pada data pengangguran tahun 2013, 2016 dan 2017 yang mengalami penurunan, namun masih terjadi kenaikan tingkat kemiskinan pada periode tersebut.

2) Hasil penelitian menunjukkan bahwa Indeks Pembangunan Manusia berpengaruh negatif tapi tidak signifikan terhadap Tingkat Kemiskinan. Hal ini mengindikasikan bahwa dengan terus meningkatnya Indeks Pembangunan Manusia, belum dapat menurunkan tingkat kemiskinan secara signifikan di Kabupaten Luwu Timur. Kondisi tersebut juga terlihat pada data Indeks Pembangunan Manusia yang terus meningkat dari tahun 2010 sampai dengan tahun 2020, namun masih terjadi kenaikan tingkat kemiskinan pada tahun 2013, 2016 dan 2017.

3) Hasil penelitian menunjukkan bahwa PDRB berpengaruh negatif tapi tidak signifikan terhadap Tingkat Kemiskinan. Hal ini mengindikasikan bahwa dengan peningkatan PDRB, belum dapat menurunkan tingkat kemiskinan secara signifikan di Kabupaten Luwu Timur. Kondisi tersebut juga terlihat pada data PDRB yang relatif meningkat dari tahun 2010 sampai dengan tahun 2020, namun masih terjadi kenaikan tingkat kemiskinan pada tahun 2013 dan 2017.

4) Hasil penelitian menunjukkan bahwa secara simultan Pengangguran, Indeks Pembangunan Manusia dan PDRB Berpengaruh Signifikan terhadap Tingkat Kemiskinan. Hal ini mengindikasikan bahwa untuk menekan tingkat kemiskinan secara signifikan di Kabupaten Luwu Timur, harus ditempuh melalui upaya mengurangi pengangguran serta peningkatan Indeks Pembangunan Manusia dan PDRB.. Hal ini mengindikasikan perlunya perhatian Pemerintah Kabupaten Luwu Timur terhadap peningkatan Indeks Pembangunan Manusia dan PDRB, serta mengatasi pengangguran dalam rangka menekan tingkat kemiskinan demi tercapainya kesejahteraan hidup bagi seluruh lapisan masyarakat.

\section{Saran}

Setelah melakukan penelitian tentang Pengaruh Pengangguran, Indeks Pembangunan Manusia dan PDRB Terhadap Tingkat Kemiskinan di Kabupaten Luwu Timur, maka di sarankan beberapa hal sebagai berikut: (1) Untuk lebih memperdalam dan memperkaya hasil penelitian selanjutnya, hasil penelitian ini diharapkan dapat dijadikan sebagai bahan acuan pengembangan penelitian lanjutan tentunya dengan memperhatikan kelemahan dan keterbatasan dalam penelitian ini. (2) Untuk lebih memperdalam dan memperkaya hasil penelitian ini, diharapkan kepada peneliti selanjutnya untuk menggunakan variabel-variabel lain diluar variabel independen yang digunakan dalam penelitian ini. (3) Pemerintah Kabupaten Luwu Timur perlu melahirkan kebijkan-kebijakan yang lebih memfokuskan untuk membuka lapangan kerja yang lebih luas untuk mengatasi pengangguran, membuka akses yang seluas-luasnya terhadap pelayanan pendidikan, kesehatan dan perekonomian serta memperluas jangkauan sektor-sektor struktur ekonomi dari perkembangan Produk Domestik Regional Bruto. (4) Pemerintah Kabupaten Luwu Timur perlu lebih memanfaatkan potensi-potensi sumber daya alam melalui peningkatan investasi yang mampu membuka lapangan kerja yang lebih luas, peningkatan Indeks Pembangunan manusia utamanya dari sisi pendidikan dan kesehatan agar ke depan dapat menyediakan sumber daya manusia yang lebih berdaya saing serta tidak hanya 
mengejar angka pertumbuhan PDRB yang tinggi tapi harus lebih berkualitas dan inklusif sehingga dapat menekan Tingkat Kemiskinan di Kabupaten Luwu Timur.

\section{DAFTAR PUSTAKA}

Andiny, P., \& Nurjannah, N. (2018). Analisis Pemberdayaan Usaha Mikro Kecil dan Menengah (UMKM) sebagai upaya Penanggulangan Kemiskinan di Kota Langsa. Jurnal Serambi Ekonomi Dan Bisnis, 5(1), 31-37.

Arfah, A., Olilingo, F. Z., Syaifuddin, S., Dahliah, D., Nurmiati, N., \& Putra, A. H. P. K. (2020). Economics During Global Recession: Sharia-Economics as a Post COVID-19 Agenda. The Journal of Asian Finance, Economics and Business, 7(11), 1077-1085.

Badan Pusat Statistik. (2018). Statistik Lingkungan Hidup Indonesia. In www.bps.go.id. Badang Pusat Statistik Indonesia. https://www.bps.go.id/publication/2018/12/07/d8cbb5465bd1d3138c21fc80/statistiklingkungan-hidup-indonesia-2018.html

BEKRAF dan BPS. (2017). Data Statistik dan Hasil Survei Ekonomi Kreatif. Kerjasama Badan Ekonomi Kreatif Dan Badan Pusat Statistik.

Benmelech, E., Frydman, C., \& Papanikolaou, D. (2019). Financial frictions and employment during the Great Depression. Journal of Financial Economics, 133(3), 541-563. https:// doi.org/10.1016/i.jfineco.2019.02.005

Claus, L., Vloeberghs, D., \& Pichault, F. (2002). Belgian-style human resource management: A case of mistaken identity. European Management Journal, 20(4), 438-446. https:// doi.org/10.1016/S0263-2373(02)00067-1

de Gregori, T. R., \& Kuznets, S. (1967). Modern Economic Growth: Rate, Structure, and Spread. Technology and Culture. https://doi.org/10.2307/3101737

Dinata, S. R. (2020). Pengaruh Indeks Pembangunan Manusia, Pertumbuhan Ekonomi, Jumlah Penduduk dan Pengangguran Terhadap Kemiskinan di Provinsi Riau Tahun 2003-2018. JURNAL AL-IQTISHAD, 16(2), 116-137.

Gaffar, S., \& Uleng Akal, A. T. (2021). Quantitative Analysis of Leverage Ratio on Earning-Per-Share of Property and Real Estate Sectors in Indonesia. Golden Ratio of Finance Management, 1(2), 101 - 113. https://doi.org/10.52970/grfm.v1i2.58

Gusfahmi. (2009). Rekonstruksi Praktek Zakat dan Pajak Untuk Menanggulangi Kemiskinan. Zakat \& Empowering - Jurnal Pemikiran Dan Gagasan, 2, 5-17.

Halvarsson, D., Korpi, M., \& Wennberg, K. (2018). Entrepreneurship and income inequality. Journal of Economic Behavior and Organization, 145, 275-293. https://doi.org/10.1016/j.jebo.2017.11.003

Inchausti-Sintes, F. (2015). Tourism: Economic growth, employment and Dutch Disease. Annals of Tourism Research, 54, 172-189. https://doi.org/10.1016/j.annals.2015.07.007

Islam, S. M. D. U., Bodrud-Doza, M., Khan, R. M., Haque, M. A., \& Mamun, M. A. (2020). Exploring COVID-19 stress and its factors in Bangladesh: A perception-based study. Heliyon, 6(7), 1-10. https:// doi.org/10.1016/j.heliyon.2020.e04399

Jamil, C. Z. M., \& Mohamed, R. (2013). The Effect of Management Control System on Performance Measurement System at Small Medium Hotel in Malaysia. International Journal of Trade, Economics and Finance, 4(4), 202-208. https://doi.org/10.7763/IJTEF.2013.V4.286

Jenkins, W. (2009). Sustainability theory. In Berkshire Encyclopedia of Sustainability.

Kaharudin, R., Kumenaung, A. G., \& Niode, A. O. (2019). Pengaruh Pengeluaran Pemerintah Terhadap Pertumbuhan Ekonomi, Pengangguran Dan Kemiskinan (Studi Kasus Pada Kota Manado Tahun 20012017). EFISIENSI, 19(04).

Kamakura, W. A., \& Mazzon, J. A. (2015). Measuring the Impact of a Conditional Cash Transfer Program on Consumption Behavior with Propensity Scoring. Customer Needs and Solutions, 2(4), 302-316. https://doi.org/10.1007/s40547-015-0037-0

Kementerian Perencanaan Pembangunan Nasional. (2016). Paket Kebijakan Ekonomi Jilid 6. 1. https://www.ekon.go.id/ekliping/view/paket-kebijakan-ekonomi-xiv.2862.html

Kurniawan, F., Adrianto, L., Bengen, D. G., \& Prasetyo, L. B. (2019). The social-ecological status of small islands: An evaluation of island tourism destination management in Indonesia. Tourism Management Perspectives, 31, 136-144. https://doi.org/https://doi.org/10.1016/j.tmp.2019.04.004

Larios-Gómez, E., Fischer, L., Peñalosa, M., \& Ortega-Vivanco, M. (2021). Purchase behavior in COVID-19: A cross study in Mexico, Colombia, and Ecuador. Heliyon, 7(3). https://doi.org/10.1016/i.heliyon.2021.e06468

LeBaron, G. (2014). Reconceptualizing Debt Bondage: Debt as a Class-Based Form of Labor Discipline. Critical Sociology. https://doi.org/10.1177/0896920513512695

Leonita, L., \& Sari, R. K. (2019). Pengaruh PDRB, Pengangguran dan Pembangunan Manusia Terhadap Kemiskinan di Indonesia. ISOQUANT: Jurnal Ekonomi, Manajemen Dan Akuntansi, 3(2), 1-8.

Liu, D., Xu, C., Yu, Y., Rong, K., \& Zhang, J. (2019). Economic growth target, distortion of public expenditure and business cycle in China. China Economic Review, December 2018, 101373. https://doi.org/10.1016/j.chieco.2019.101373 
Mahdalena, M., Haliah, Syarifuddin, \& Said, D. . (2021). Budget Accountability in The Perspective of Habermas Communicative Action Theory. Golden Ratio of Social Science and Education, 1(2), 61 - 72. https://doi.org/10.52970/grsse.v1i2.73

Maksimov, V., Wang, S. L., \& Luo, Y. (2017). Reducing poverty in the least developed countries: The role of small and medium enterprises. Journal of World Business, 52(2), 244-257. https://doi.org/10.1016/j.jwb.2016.12.007

O'Campo, P., Molnar, A., Ng, E., Renahy, E., Mitchell, C., Shankardass, K., St. John, A., Bambra, C., \& Muntaner, C. (2015). Social welfare matters: A realist review of when, how, and why unemployment insurance impacts poverty and health. Social Science and Medicine, 132, 88-94. https://doi.org/10.1016/i.socscimed.2015.03.025

Olilingo, F. Z., \& Putra, A. H. P. K. (2020). How Indonesia Economics Works: Correlation Analysis of Macroeconomics in 2010-2019. Journal Asian Finance Economic and Business, 7(8), 117-130.

Perpres No. 166 Tahun 2014. (2014). Peraturan Presiden Republik Indonesia Program Percepatan Penanggulangan Kemiskinan (pp. 8-11).

Prasetyoningrum, A. K., \& Sukmawati, U. S. (2018). Analisis Pengaruh Indeks Pembangunan Manusia (IPM), Pertumbuhan Ekonomi dan Pengangguran Terhadap Kemiskinan di Indonesia. Equilibrium: Jurnal Ekonomi Syariah, 6(2), 217-240.

R, A. H., Ekonomi, J. I., Ekonomi, F., Bisnis, D. A. N., \& Hasanuddin, U. (2013). Analisis Penyerapan Tenaga Kerja Industri Tenun Sutera di Kabupaten Wajo.

Rachmawati, M. (2020). Kontribusi Sektor Umkm Pada Upaya Pengentasan Kemiskinan Di Indonesia. Jurnal Ekonomi, Sosial \& Humaniora, 1(07), 1-13.

Raišienė, A. G., Bagdonienė, J., \& Bilan, Y. (2014). Inter-Institutional Interaction Results: The Effect of EU Programs on the Reduction of Long-term Unemployment. Procedia Economics and Finance, 16(May), 641650. https://doi.org/10.1016/s2212-5671(14)00852-1

Rombe, Y. (2021). The Analysis of Financial Statements Performance: Case Studies PT. Bank Negara Indonesia (Persero) . Golden Ratio of Finance Management, 1(2), 87 - 100. https:// doi.org/10.52970/grfm.v1i2.53

Setyawan, A. A. (2007). Kemiskinan Di Duma Ketiga Dalam Perspektif Ekonomipolitikinternasional. Jurnal Ekonomi Pembangunan: Kajian Masalah Ekonomi Dan Pembangunan, 2(2), 119. https://doi.org/10.23917/jep.v2i2.3910

Sessu, A., Samiha, Y. T., Laisila, M., Chamidah, N., Murdifin, I., \& Putra, A. H. P. K. (2021). The Effect of Macroeconomic Factors on Income Inequality: Evidence from Indonesia. The Journal of Asian Finance, Economics and Business, 8(7), 55-66.

Sha, F., Li, B., Law, Y. W., \& Yip, P. S. F. (2019). Beyond the Resource Drain Theory: Salary satisfaction as a mediator between commuting time and subjective well-being. Journal of Transport \& Health, 15, 100631. https://doi.org/https://doi.org/10.1016/j.jth.2019.100631

Shammi, M., Bodrud-Doza, M., Towfiqul Islam, A. R. M., \& Rahman, M. M. (2020). COVID-19 pandemic, socioeconomic crisis and human stress in resource-limited settings: A case from Bangladesh. Heliyon, 6(5). https:// doi.org/10.1016/j.heliyon.2020.e04063

Sitopu, Y. B., Sitinjak, K. A. ., \& Marpaung, F. K. . (2021). The Influence of Motivation, Work Discipline, and Compensation on Employee Performance. Golden Ratio of Human Resource Management, 1(2), 72 - 83. https://doi.org/10.52970/grhrm.v1i2.79

Sugiyono. (2010). Metode Penelitian Kuantitatif Dan Kualitatif Dan R\&D. Alfaeta.

Sukirno, D. S., \& Siengthai, S. (2011). Does participative decision making affect lecturer performance in higher education? International Journal of Educational Management, 25(5), 494-508.

Sukirno, S. (2004). Makroekonomi teori pengantar. Jakarta: PT Raja Grafindo Persada.

Syafitry Sitorus, D., Amelia Putri, A. ., Rahmat Hidayat, P., \& Rostina, C. F. . (2021). The influence of Selection, Motivation and Utilization of Information System Academic for Lecturer (SIAD) on the Lecturer Performance . Golden Ratio of Human Resource Management, 1(2), $61 \quad$ - 71. https://doi.org/10.52970/grhrm.v1i2.78

Suripto, S., \& Subayil, L. (2020). Pengaruh Tingkat Pendidkan, Pengangguran Pertumbuhan Ekonomi Dan Indeks

Pembangunan Manusia Terhadap Kemiskinan Di Di Yogyakarta Priode 2010-2017. GROWTH Jurnal Ilmiah Ekonomi Pembangunan, 1(2), 127-143.

Tian, S., \& Liu, Z. (2020). Emergence of income inequality: Origin, distribution and possible policies. Physica A: Statistical Mechanics and Its Applications, 537. https://doi.org/10.1016/j.physa.2019.122767

Umar, Z., \& Gubareva, M. (2020). A time-frequency analysis of the impact of the Covid-19 induced panic on the volatility of currency and cryptocurrency markets. Journal of Behavioral and Experimental Finance, 28, 100404. https:// doi.org/10.1016/j.jbef.2020.100404

Wang, W., Phillips, P. C. B., \& Su, L. (2019). The heterogeneous effects of the minimum wage on employment across states. Economics Letters, 174, 179-185. https://doi.org/10.1016/j.econlet.2018.11.002 
www.bbc.com. (2014). Ketimpangan pendapatan berdampak pada pertumbuhan ekonomi - BBC News Indonesia. Online Webpage. https://www.bbc.com/indonesia/majalah/2014/12/141209_bisnis_ketimpangan_pendapatan

Yudha, O. R. P. (2013). Pengaruh pertumbuhan ekonomi, upah minimum, tingkat pengangguran terbuka, dan inflasi terhadap kemiskinan di indonesia tahun 2009-2011. Universitas Negeri Semarang. 